\title{
SHELTERING GOVERNMENT SUPPORT TO 'GREEN' ELECTRICITY: THE EUROPEAN UNION AND THE WORLD TRADE ORGANIZATION
}

\begin{abstract}
Since the Canada - Renewable Energy (2013) dispute at the World Trade Organization (WTO), the WTO Agreement on Subsidies and Countervailing Measures (SCM) has been the focal point of academic debate on the trade and environment interface, with a growing consensus that WTO subsidy rules need to be revisited with a view to securing 'policy space' for government support to renewable energy. This article explores whether, as suggested by some scholars, the European Union (EU)'s system of justifications for renewable energy aid could serve as a source of inspiration for the WTO. While this proposition may appear attractive at first sight, it is hardly conceivable, or even desirable, that the EU's approach to sheltering renewable energy government support could be transposed to the WTO. This is because the two systems of subsidy control are fundamentally different in both substantive and procedural terms and, importantly, these differences reflect distinct objectives and political/institutional contexts. Nonetheless, this comparative analysis is used to shed light on where the key challenges lay for the W'TO in ensuring mutual supportiveness between international trade rules and climate change mitigation objectives. It is argued that the case for reviewing the SCM Agreement cannot be made by simply forging parallels with the EU's regulatory model, but needs to be carefully construed on the basis of a proper understanding of whether and how green policy space is actually constrained under the current WTO subsidy and trade remedy rules. However, this requires better information on existing WTO members' practice in relation to renewable energy subsidies, as well as on their environmental effectiveness and possible trade-distortive impact. In this sense, the most valuable lesson that the WTO can draw from the EU's regulatory experience is the imperative of improving the transparency and knowledge-enhancing side of its subsidy control system.
\end{abstract}

\section{INTRODUCTION}

Following the World Trade Organization (WTO) Appellate Body report in the CanadaRenewable Energy (2013) dispute, ${ }^{1}$ the need for reforming the WTO Agreement on Subsidies and Countervailing Measures (SCM) has been increasingly voiced in the literature, in particular with a view to safeguarding 'policy space' for government support to renewable energy (RE). ${ }^{2}$ The essence of the call for reform is that the current SCM

\footnotetext{
1 WTO Appellate Body Report, Canada - Certain Measures affecting the Renewable Energy Generation Sector/Measures relating to the Feed-in Tariff Program, WT/DS412/DS426/AB/R, adopted 24 May 2013 [Canada-Renewable Energy (2013)].

${ }^{2}$ Pioneering this call for reform is: L. Rubini, 'Ain't Wastin Time No More: Subsidies for Renewable Energy, the SCM Agreement, Policy Space and Law Reform’ (2012) 15(2) Journal of International Economic Law 525. Subsequent contributions in this direction include: L. Casier and T. Moerenhout, "WTO Members, Not the Appellate Body, Need to Clarify the Boundaries in Renewable Energy Support' (International Institute for Sustainable Development, July 2013), https://www.iisd.org/pdf/2013/wto_members_renewable_energy_support.pdf; A. Cosbey and P.C. Mavroidis, 'A Turquoise Mess: Green Subsidies, Blue Industrial Policy and Renewable Energy - the Case for Re-drafting the Subsidies Agreement of the WTO’ (2014) 17(1) Journal of International Economic Law 11; P. D. Farah and E. Cima, 'The World Trade Organization, Renewable Energy Subsidies, and the Case of Feed-in Tariffs: Time for Reform Towards Sustainable Development' (2015) 27 Georgetown International Environmental Law Review 515; R. Howse, 'Securing Policy Space for Clean Energy under the SCM Agreement: Alternative Approaches' (International Centre for Trade and Sustainable Development/World Economic Forum, December 2013), http://e15initiative.org/publications/securing-policy-space-for-cleanenergy-under-the-scm-agreement-alternative-approaches/; S. Shadikhodjaev, 'Renewable Energy and
} 
disciplines, which were negotiated and designed in the late 1980s and early 1990s, are no longer suitable in the face of the imperative of addressing climate change among other global public goods. In the particular case of RE support measures, their legal status as 'subsidies' that can be challenged under the SCM Agreement is unclear, and this legal uncertainty itself is claimed to be a constraint on policy space. Most fundamentally, it is argued that the problem with the SCM Agreement is that there is no basis for accommodating trade-distortive renewable energy subsidies: if these are contingent on export performance or import-substitution (Article $3 \mathrm{SCM}$ ), or are otherwise shown to cause 'adverse effects' (Article $5 \mathrm{SCM}$ ) to the import-competing or export-competing interests of another member, there are WTO-illegal with no possibility of defence. This is so irrespective of the rationale for subsidization: the text of the SCM Agreement is not any more tolerant towards the trade-distortive effects of a subsidy that contributes to mitigating climate change or any other legitimate policy objective. Against this growing consensus on the need to review the SCM Agreement, some scholars have suggested turning to the European Union (EU) as a possible source of inspiration, given it is the only other polity that has a centralised system of subsidy control. ${ }^{3}$

While this proposition may appear attractive at first sight, it necessitates closer analysis and careful reflection. In this sense, the present article is a first attempt at thoroughly exploring which lessons, if any, may the WTO draw from the EU in terms of sheltering government support to the development and use of renewable energy, with a particular focus on electricity produced from renewable energy sources (or 'green' electricity). In order to do so, it begins by examining the relationship between climate change mitigation, renewable energy and government intervention so as to place the comparative analysis into its broader legal and policy context. It will be shown that while renewable energy has been widely recognized to play an important role in achieving the internationally-agreed $2^{\circ} \mathrm{C}$ climate target, and the need for government intervention to boost renewable energy generally accepted, a more controversial issue remains which specific forms of public support are most appropriate or effective towards combating climate change (Section 2). And yet, as will be seen, this question is particularly relevant from a WTO law standpoint, as different support measures will fare differently when examined under the microscope of the SCM Agreement. The article then proceeds with an in-depth comparative analysis of the EU and WTO regulatory frameworks on government support to green electricity. It will be shown that whilst the two systems present some similarities in their approach to negative integration, they are fundamentally different in important respects. Overall, EU substantive disciplines and control mechanisms are comparatively much stronger, which is a direct reflection of the more ambitious objectives of EU State aid law. This, in turn, goes a long way in explaining why the EU's regulatory model is also distinct for having progressively established a sophisticated system of justifications for State aid to renewable energy, using a combination of both hard-law and soft-law instruments (Section 3). However, it will be

Government Support: Time to Green the SCM Agreement?' (2015) 14(3) World Trade Review 479. For a more nuanced stance, see D. P. Steger, 'Green Energy Programs and the WTO Agreement on Subsidies and Countervailing Measures: A Good FIT?’ (2015) Ottawa Faculty of Law Working Paper 2015/20, https://papers.ssrn.com/sol3/papers.cfm?abstract id=2591083.

${ }_{3}$ This has been mainly advocated by Luca Rubini, but without in-depth elaboration: see Rubini (n 2), at 577, and L. Rubini, 'Rethinking International Subsidies Disciplines: Rationale and Possible Avenues for Reform' (International Centre for Trade and Sustainable Development/World Economic Forum, November 2015), at 4-5, http://e15initiative.org/publications/rethinking-international-subsidiesdisciplines-rationale-and-possible-avenues-for-reform/. See also, S. Z. Bigdeli, 'Resurrecting the Dead? The Expired Non-Actionable Subsidies and the Lingering Question of "Green Space" (2011) 8(2) Manchester Journal of International Economic Law 2, at 10-23, drawing lessons from the EU's regulatory approach for the WTO but preceding Canada - Renewable Energy (2013). 
argued that the EU's experience in sheltering renewable energy aid cannot be easily replicated at the WTO level for a variety of legal, political and institutional reasons (Section 4).

Nonetheless, this comparative analysis is used to shed light on where the key challenges lay for the WTO in ensuring mutual supportiveness between international trade rules and climate change mitigation objectives. Arguably, the most pressing one is to improve the transparency and knowledge-enhancing side of the WTO subsidy control system, so that it is becomes clearer which green policy space is actually at stake. In other words, what RE support measures are being implemented by WTO members and is there a conceivable risk these are constrained under current WTO rules? In this regard, it will be questioned whether what needs to be revisited is the SCM Agreement alone or rather WTO trade remedy rules more generally (including the Anti-dumping Agreement), on which the EU can hardly offer any guidance (Section 5).

\section{CLIMATE CHANGE MITIGATION, RENEWABLE ENERGY AND GOVERNMENT SUPPORT}

\section{A. International Framework and Practice}

It is largely uncontested that climate change is possibly the greatest sustainable development challenges presently facing the international community. ${ }^{4}$ The 1992 United Nations Framework Convention on Climate Change (UNFCCC), with its near-universal membership, represents the global response to this challenge with the ultimate objective of stabilising 'greenhouse gas emissions concentrations in the atmosphere at a level that would prevent dangerous anthropogenic interference with the climate system. ${ }^{5}$ To this end, the main scientific authority for climate policymaking -the Intergovernmental Panel on Climate Change (IPCC) - has estimated that global greenhouse gas (GHG) emissions would need to be reduced to close to zero during the second half of this century in order to achieve the global target of limiting average temperature increase to below $2^{\circ} \mathrm{C}$ from pre-industrial times. ${ }^{6}$ This commitment has been recently enshrined into the landmark Paris Agreement, which entered into force on 4 November 2016, and whose overarching goal of 'holding the increase in the global average temperature to well below $2^{\circ} \mathrm{C}$ above pre-industrial levels ${ }^{37}$ is to be implemented by all Parties through 'nationally determined contributions'. ${ }^{8}$ Similarly, there is broad acceptance that replacing conventional 'brown' or 'dirty' energy (i.e. generated from fossil fuels such as coal, natural gas and oil) with

\footnotetext{
${ }^{4}$ See, inter alia, United Nations Environment Programme/World Trade Organisation, Report on Trade and Climate Change (2009) [UNEP/WTO Report 2009], at v.

${ }^{5}$ United Nations Framework Convention on Climate Change, signed on 9 May 1992, 771 U.N.T.S. 107, Art 2.

${ }^{6}$ Intergovernmental Panel on Climate Change, 'Summary for Policymakers' in O. Edenhofer et al. (eds), Climate Change 2014: Mitigation of Climate Change - Contribution of Working Group III to the Fifth Assessment Report of the Intergovernmental Panel on Climate Change (Cambridge University Press, 2014) [IPCC Report 2014], at 12. ${ }_{7}^{7}$ Paris Agreement, concluded 12 December 2015, Art 2(1)(a).

8 Ibid., Arts 3 and 4(2). Note that this was ground-breaking vis-à-vis the UNFCC division between 'Annex I Parties' (43 in total, considered 'developed countries' with first- or second-period Kyoto GHG emission reduction targets) and 'non-Annex I Parties' (the vast majority, considered 'developing countries' with no GHG emission reduction targets), the latter group being greatly heterogeneous and including large emerging economies with significant GHG emissions (such as Brazil, China, India and South Africa) and rich fossil-fuel producing nations (such as Saudi Arabia, Qatar and United Arab Emirates). Scientific estimates, however, have shown that it was not possible to achieve the $2{ }^{\circ} \mathrm{C}$ climate target without 'developing-country' action: see further, K. Kulovesi, 'Real or Imagined Controversies? A Climate Law Perspective on the Growing Links Between the International Trade and Climate Change Regimes' (2014) 6(1) Trade, Law and Development 54, at 64-65.
} 
renewable 'green' or 'clean' energy (i.e. generated from naturally replenished resources such as solar, wind, geothermal and hydropower) can play an important role in mitigating climate change and achieving the internationally agreed $2{ }^{\circ} \mathrm{C}$ climate target. ${ }^{9}$ This is because the energy sector is by far the largest source of greenhouse gas emissions, being responsible for more than two-thirds of worldwide GHG emissions, with fossil fuels being the source of about $80 \%$ of those emissions and in particular electricity produced from fossil fuels accounting for $40 \%$ of them. ${ }^{10}$

A much more complex question, however, is whether government support to renewable energy is needed to ensure the transition to a low-carbon green economy. According to economic theory, government intervention may be warranted whenever the market fails to deliver desirable public goods or/and to tackle externalities. From this angle, climate change is often posited as the 'greatest and widest-ranging market failure ever seen' whose overall costs, if unaddressed, have been estimated as equivalent to losing at least $5 \%$ (and as much as $20 \%$ ) of the world's gross domestic product 'each year, now and forever'. ${ }^{11}$ Part of the problem is that market prices do not properly factor the climate-related benefits (or positive externalities) of green energy, and as a result profitmaximising private companies will typically under-produce or under-invest in renewable energy and associated technologies due to private production/investment costs exceeding private benefits. ${ }^{12}$ This provides a persuasive justification for public support as a means to incentivize and compensate renewable energy producers for their contribution towards achieving a significant global public good -i.e. a stable climate. ${ }^{13}$ In addition, the case for government support is made stronger by the need for a rapid and extensive dissemination of renewable energy, given the undisputed urgency of addressing climate change and reducing global GHG emissions substantially (i.e. by $40-70 \%$ in 2050 compared to 2010 and close to zero in 2100 if the $2^{\circ} \mathrm{C}$ climate target is to be achieved).$^{14}$

The other part of the problem is that market prices also fail to capture the real climate-related costs (or negative externalities) of conventional energy, making it relatively cheap vis-à-vis renewable energy. ${ }^{15}$ This market failure is further exacerbated by the fact that the end-user price of conventional energy continues to be artificially lowered through heavily subsidised fossil fuels. According to the latest data by the International Energy Agency (IEA), worldwide fossil-fuel subsidies totalled $\$ 510$ billion in 2014 -an equivalent incentive of $\$ 115$ per tonne of carbon dioxide emitted. ${ }^{16}$ Correcting these market distortions, however, is only a second-best reason for government intervention in support of green energy. ${ }^{17}$ From an economic efficiency standpoint, the first-best government response to put renewable energy on an equal footing with competing and underpriced conventional energy would be to internalise climate-related costs by imposing a carbon tax at the socially optimum level, coupled with a (gradual) phasing-out

\footnotetext{
${ }^{9}$ On this point, see Kulovesi (n 8), at 85-88.

${ }^{10}$ International Energy Agency, Redrawing the Energy-Climate Map - World Energy Outlook Special Report (2013) [IEA Report 2013], at 15; and Energy and Climate Change - World Energy Outlook Special Report (2015) [IEA Report 2015], at 20.

11 N. Stern, The Economics of Climate Change: Stern Review (Cambridge University Press 2007), Executive Summary, at $\mathrm{i}$ and iv, referred to in inter alia: Cosbey and Mavroidis (n 2), at 29 and Rubini (n 2), at 528.

12 Shadikhodjaev (n 2), at 484.

13 See inter alia, International Institute for Sustainable Development/United Nations Environment Programme, Trade and Green Economy - A Handbook (2014) [IISD/UNEP Handbook 2014], at 94; S. Charnovitz, 'Green Subsidies and the WTO' (2013) EUI Working Papers RSCAS 2014/93, at 1-3, http://cadmus.eui.eu/bitstream/handle/1814/32791/RSCAS 2014 93.pdf?sequence=1.

${ }^{14}$ IPPC Report 2014 (n 6), at 13.

${ }^{15}$ Charnovitz (n 13), at 2; P. D. Farah and E. Cima, 'WTO Law and Renewable Energy: Lessons from the Case Law' (2015) 49(6) Journal of World Trade 1103, at 1105.

${ }^{16}$ IEA Report 2015 (n 10), at 90.

${ }^{17}$ D. Rodrik, 'Green Industrial Policy' (2014) 30(3) Oxford Review of Economic Policy 469, at 470.
} 
of distortive fossil-fuel subsidies. ${ }^{18}$ Indeed, both measures have been singled out as an essential component of the climate policy mix by the IPCC, ${ }^{19}$ as well as by the IEA in its recent 'Bridge Scenario' to secure the decarbonisation of the energy sector in order to stay below the $2^{\circ} \mathrm{C}$ climate limit. ${ }^{20} \mathrm{In}$ this regard, Howse rightly notes that there is 'a very limited logic to giving policy space for clean-energy incentives or support to WTO Members who undermine the sought-after environmental benefits by, at the same time, continuing to subsidize dirty energy. ${ }^{21}$ And yet, this ideal approach of pricing carbon and removing climate-harmful subsidies to conventional energy may be politically difficult to implement and only gradually introduced in practice. ${ }^{22}$ These political economy considerations may further reinforce the case for (even imperfect) government intervention to level the playing field, at least in favour of those climate-friendly technologies that are not yet cost-competitive (absent that public support) with other brown energy sources. ${ }^{23}$

But even if ones accepts there is a reasonable theoretical justification for government intervention to boost renewable energy at the general level, this still leaves open the question of which specific support measures are most appropriate or effective towards combating climate change. The UNFCC regime does not provide much guidance on this question since, as most multilateral environmental agreements, it leaves the issue of instrument choice to the Contracting Parties. ${ }^{24}$ This decentralised approach is sensible as there is no one-size-fits-all approach to climate change mitigation for over 190 States with highly divergent GHG emissions profiles and potentials for renewable energy. ${ }^{25}$ When looking at policy practice, the promotion of green electricity generation (particularly using solar photovoltaic (PV) and wind technologies) continues to be the focus of government stimulus ${ }^{26}$ with the single most common form of support being feed-in tariff (FIT) schemes that offer long-term guaranteed prices for renewably generated electricity fed into the grid. According to the global Renewable Energy Policy Network (REN21), as of year-end 2015, 110 jurisdictions at the national or state/provincial level had FIT programmes in place. ${ }^{27}$ Significantly, this implies an increase by 11 vis-à-vis $2013^{28}$ when the Appellate Body's ruling in Canada - Renewable

\footnotetext{
18 Bigdeli (n 3), at 28.

${ }^{19}$ IPCC Report 2014 (n 6), at 28-29.

${ }^{20}$ IEA Report 2015 (n 10), at 13 and 135; see also IEA Report 2013 (n 10), at 11.

${ }^{21}$ Howse (n 2), at 1.

22 IEA Report 2013 (n 10), at 67-90; and IEA Report 2015 (n 10), at 91-93 for an overview of selected national experiences with fossil-fuel subsidy reform.

${ }^{23}$ See, for example, International Renewable Energy Agency, REmap 2030: A Renewable Energy Roadmap Summary of Findings (2014), at 11-12, aimed at achieving a RE share of at least 30\% in the global energy mix to secure the $2^{\circ} \mathrm{C}$ climate target and whose implementation assumes worldwide RE subsidies to rise to $\$ 315$ billion in 2030; see also, International Energy Agency, World Energy Outlook - A Renewable Energy Outlook (2012) [IEA Report 2012], at 234-235, estimating total renewable energy subsidies to reach almost $\$ 240$ billion per year by 2035 in its 'New Policies Scenario', with solar PV and offshore wind technologies requiring public support worldwide (outside of limited niche applications) through 2035; and IEA Report 2015 (n 10), at 21.

${ }^{24}$ See, for example, Art 2.1(a) (iv) of the Kyoto Protocol to the United Nations Framework Convention on Climate Change, signed on 11 December 1997, 2303 UNTS 148, which generally recognizes that GHG emission reductions may be achieved through the "promotion, development and use of new and renewable forms of energy" but leaves Parties ample scope to decide which RE promotion measures to implement.

${ }^{25}$ Kulovesi (n 8), at 69.

${ }^{26}$ REN21, Renewables 2016 - Global Status Report (2016) [REN21 Report 2016], at 8; see also IEA Report 2012 (n 23), at 234, estimating that renewable energy subsidies stood at $\$ 88$ billion in 2011, with $\$ 66$ billion going to electricity and solar PV receiving more than any other technology for green electricity generation ( $\$ 25$ billion), followed by wind ( $\$ 21$ billion) and bioenergy ( $\$ 15$ billion).

${ }^{27}$ REN21 Report 2016 (n 26), at 8.

${ }^{28}$ REN21, Renewables 2013 - Global Status Report (2013) [REN21 Report 2013], at 68.
} 
Energy (2013) was delivered. Thus, the uncertainty surrounding the legal status of FITs under the SCM Agreement following that WTO report ${ }^{29}$ does not seem to have had a 'chilling effect' on policy practice. Besides being a popular choice, this price-support mechanism (if 'well-designed' and 'well-implemented') has been widely recognised as the 'most efficient and effective' policy instrument for promoting green electricity by the IPPC and other international expert bodies. ${ }^{30}$ Another common form of government support in the electricity sector are fiscal measures (e.g. tax exemptions/reductions) and public finance (e.g. grants and preferential loans) to encourage investment in and deployment of renewable energy technologies, ${ }^{31}$ and have been projected to increase substantially in the IEA's 'Bridge Scenario' from $\$ 270$ billion in 2014 to $\$ 400$ billion in $2030 .{ }^{32}$

From an international trade perspective, however, it is important to distinguish between government support to generators of green electricity itself (such as FIT schemes) and to manufacturers of green technology products (such as investment aid). This is because the electricity market has traditionally been local, with cross-border electricity trade restrained by geography and grid connection infrastructure. Indeed, recent IEA statistics show that cross-border electricity trade mainly occurs between neighbour or contiguous countries, and while steadily increasing, global imports (726 TWh) of electricity in 2015 only amounted to about 3.5\% of the world's total final electricity consumption (20200 TWh). ${ }^{33}$ These physical constraints of electricity distribution systems necessarily limit the international trade impact of government support to green electricity and, as will be seen, this has a bearing on the question of policy space under WTO law. ${ }^{34}$ By contrast, the market for RE generation equipment is a global market, with clean technology components (e.g. solar PV cells and modules or wind turbines) traded intensively across borders. For instance, for PV solar modules, China supplied about 30\% of the global market in 2013 followed by the United States (US) and Japan, while for wind turbines the top suppliers were Germany, China, US, Denmark, India and Spain. ${ }^{35}$

\section{B. EU Framework and Practice}

For its part the European Union has set for itself the more ambitious targets, to be attained by 2020, of increasing the share of renewable energy to at least $20 \%$ in EU final energy consumption and to at least $10 \%$ of energy used in the transport sector in each Member State (the bulk of which is expected to come from biofuels). ${ }^{36}$ These $2020 \mathrm{RE}$

\footnotetext{
${ }^{29}$ On this point, see further section III.A below.

${ }^{30}$ Intergovernmental Panel on Climate Change, Renewable Energy Sources and Climate Change Mitigation Summary for Policy Makers and Technical Summary (2012), at 152, outlining the main elements of 'well-designed' FIT programmes; see also S. Charnovitz and C. Fischer, 'Canada - Renewable Energy: Implications for WTO on Green and Not-So-Green Subsidies' (2015) 14(2) World Trade Review 177, at 184, referring to estimates that FITs are responsible for about $75 \%$ of global solar PV and $45 \%$ of global wind capacity.

${ }^{31}$ For an overview, see REN21 Report 2013 (n 28), at 68-70; and REN21 Report 2016 (n 26), at 8.

32 IEA Report 2015 (n 10), at 13 and 85.

33 International Energy Agency, 'Electricity Information: Overview' (2017), at 5 and 7-8, https://www.iea.org/publications/freepublications/publication/ElectricityInformation2017Overview.pdf. A significant difference can be noticed between OECD countries, where total electricity imports amounted to $488 \mathrm{TWh}$ (about $4.4 \%$ of OECD final electricity consumption) and the bulk of trade flows occurred within the EU integrated electricity market, and non-OECD countries, where total electricity imports amounted to $238 \mathrm{TWh}$ (about $2.2 \%$ of non-OECD final electricity consumption).

${ }^{34}$ See further section III.A below.

${ }^{35}$ Charnovitz and Fischer (n 30), at 184-185.

${ }^{36}$ Directive 2009/28/EC of the European Parliament and of the Council of 23 April 2009 on the promotion of the use of energy from renewable sources, OJ [2009] L140/16 [2009 Renewable Energy
} 
targets are a central piece of the EU's climate change mitigation strategy, ${ }^{37}$ given that energy-related emissions accounted for almost $80 \%$ of its total GHG emissions in $2010 .{ }^{38}$ However, increasing the use of renewable energy is also seen as a means to reduce the EU's dependence on imported fossil fuels, especially on imported oil in the transport sector, ${ }^{39}$ and thereby strengthen its international competitiveness. In other words, the ambition is also to foster the development of domestic RE industries and drive technological innovation and job-creation across Europe. ${ }^{40}$ This industrial policy goal is not unique to EU policy practice but also found under other RE support programmes (typically by attaching local content requirements), ${ }^{41}$ and as will be discussed is most problematic from a WTO law standpoint. ${ }^{42}$

The 2009 Renewable Energy Directive establishes a common framework for the promotion of renewable energy and translates the overall 2020 targets into mandatory and differentiated national targets for each EU Member State (MS). ${ }^{43}$ To achieve these national targets, Member States are required to adopt national renewable energy action plans, ${ }^{44}$ specifying sectoral 2020 targets for the share of energy from renewables in electricity, heating and cooling, and transport; planned policy measures to achieve them; the different mix of RE technologies they expect to employ; and the planned use of cooperation mechanisms. ${ }^{45}$ Of most relevance to our purposes, ${ }^{46}$ the Directive

Directive], Arts 3(1) and (4). These renewable energy targets were previously advanced in: European Commission, 'Communication on Renewable Energy Roadmap - Renewable Energies in the $21^{\text {st }}$ Century: Building a more Sustainable Future’ COM(2006) 848final, 10 January 2007.

${ }^{37}$ The 2020 climate and energy targets further include: (i) reducing greenhouse gas emissions by $20 \%$ from 1990 levels; and (ii) improving energy efficiency by 20\%. These were endorsed by the European Council, 'Presidency Conclusions - Brussels, 8/9 March 2007' (7224/1/07), 2 May 2007, at 10-12 and 19-18. To implement these 2020 targets, the EU adopted a package of measures in 2009: see inter alia, K. Kulovesi, E. Morgera and M. Muñoz, 'Environmental Integration and Multi-Faceted International Dimensions of EU Law: Unpacking the EU’s 2009 Climate and Energy Package' (2011) 48(3) Common Market Law Review 829.

${ }^{38}$ European Commission, 'Communication on Energy 2020 - A Strategy for Competitive, Sustainable and Secure Energy’ COM(2010) 639final, 10 November 2010 [Communication Energy 2020], at 2.

392009 Renewable Energy Directive (n 36), Preamble, paras 2 and 5.

${ }^{40}$ Ibid, Preamble, para 4.

${ }^{41}$ See notably Appellate Body Report, Canada - Renewable Energy (2013) (n 1), paras 4.17 and 4.21-4.22, where electricity generators using wind or solar PV technology (but not other covered renewable energy sources) could qualify for the guaranteed prices under the FIT programme (20-year contracts) only if they utilised a certain percentage of Ontario-produced RE generation equipment (e.g. Ontario-made wind turbines or solar panels) in developing and constructing their generation facilities. More generally see, J. I. Lewis, 'The Rise of Renewable Energy Protectionism: Emerging Trade Conflicts and Implications for Low Carbon Development' (2014) 14 (4) Global Environmental Politics 10.

42 See section III.A below.

432009 Renewable Energy Directive (n 36), Annex 1, part A, where national targets for the share of renewable energy in final energy consumption range from $10 \%$ in Malta to $49 \%$ in Sweden.

44 Ibid, Art 4 and Annex VII. These national action plans may be found at: http://ec.europa.eu/energy/node/71.

45 The Renewable Energy Directive introduces a number of cooperation mechanisms aimed at facilitating the achievement of the 2020 national targets, notably: (i) statistical transfers of a specified amount of renewable energy from one MS to another MS (Article 6); (ii) joint projects, whereby two or more MS may co-finance and implement a project for the production of electricity, heating or cooling from renewable energy sources, and share the resulting renewable energy for the purpose of meeting their national targets (Article 7); (iii) joint support schemes, whereby two or more MS may decide to join or partly coordinate their national support schemes, and in such cases, a certain amount of renewable energy produced in the territory of one participating MS may (under certain conditions) count towards the national target of another MS (Article 11); and (iv) joint projects by one or more MS may with third countries regarding the production of electricity from renewable energy sources (Article 9).

${ }^{46}$ Space limitations do not allow for a comprehensive examination of the EU Renewable Energy Directive and thus only its most relevant provisions for RE support schemes will be discussed here. For a more detailed account, see Kulovesi, Morgera and Muñoz (n 37), at 874-887. A particularly salient feature of the Directive are the provisions establishing sustainability criteria for biofuels and bioliquids, whereby only 
contemplates that Member States may introduce support schemes to promote the use of energy from renewable sources, subject to the Treaty provisions on State aid. ${ }^{47}$ It further provides an indicative list of public support measures that can encourage the use of renewable energy by reducing the cost of that energy (e.g., investment aid to reduce the capital costs of installing and deploying RE technologies, or tax exemptions/reductions), by increasing its sales price (e.g., through direct price-support mechanisms such as FITs and premium payments), or by increasing its sales volume (e.g., through RE quota obligations, with or without tradable green certificates) ${ }^{48}$ In a similar vein to the UNFCC, the EU legislative framework thus adopts a decentralised approach to choice of RE support instruments, with Member States remaining the main drivers of policy development in this field. As may be expected, this has led to large differences in terms of both support levels and instruments across EU Member States. According to the European Commission, the production of green electricity has been most commonly aided through direct price-support mechanisms (24 MS), followed by grants and preferential loans (17 MS), fiscal measures (12 MS) and quantity-based mechanisms (6 MS). ${ }^{49}$

In the run-up to the adoption of the 2009 Renewable Energy Directive, the European Commission raised concerns about the multitude of national support schemes from the perspective of the internal electricity market. Nonetheless, it considered then that 'harmonisation of support schemes would be premature, as the internal electricity market is not functioning properly, greater interconnector capacity is needed, national support to conventional electricity producers continue to distort the market and there has not been sufficient experience accumulated to determine the best choice of support scheme. ${ }^{50}$ As will be seen, this position has been recently revisited following the adoption of the Guidelines on State Aid for Environmental Protection and Energy (EEA Guidelines) in April 2014. ${ }^{51}$

Finally, it ought to be highlighted that, according to the latest Commission renewable energy progress report, considerable progress has been made towards meeting the 2020 targets: in 2014, the projected share of RE in EU final energy consumption was $15.3 \%$, with $10 \%$ share in electricity, $16.6 \%$ share in cooling and heating, and $5.7 \%$ in transport. ${ }^{52}$ Based on current developments and policies, it is estimated that the share of RE in EU final energy consumption could reach $20.9 \%$ in $2020 .{ }^{53}$ And yet, the promotion of renewable energy will continue to play a key role in the transition towards

conforming biofuels and bioliquids may count towards meeting the obligatory national RE targets in the transport sector and/or be eligible for financial support (Article 17). These have been in the international spotlight for several reasons, including their WTO-compatibility: see World Trade Organization, European Union and Certain Member States - Certain Measures on the Importation and Marketing of Biodiesel and Measures Supporting the Biodiesel Industry - Request for Consultations by Argentina, 23 May 2013, WT/DS459/1; and further discussion in A. Swinbank and C. Daugbjerg, 'Improving EU Biofuels Policy? Greenhouse Gas Emission, Policy Efficiency and WTO Compatibility' (2013) 47(4) Journal of World Trade 813.

472009 Renewable Energy Directive (n 36), Art 3(3).

48 Ibid, Art 2(k).

${ }^{49}$ European Commission, 'Staff Working Document - Guidance for the Design of Renewable Support Schemes' SWD(2013) 439 final [Commission WD 2013], Table 2, at 25; and 'Study by the Chamber of Commerce and Industry for Munich and Upper Bavaria', Table 2, at 17-21. See also, European Commission, 'Competition Policy Brief - Improving State Aid for Energy and the Environment', October 2014 [Commission Policy Brief 2014], at 2 for variations in support levels.

${ }^{50}$ European Commission, 'Staff Working Document - The Support of Electricity from Renewable Energy Sources' $\operatorname{COM}(2008)$ 19final, 23 January 2008, at 14.

${ }^{51}$ European Commission, 'Guidelines on State Aid for Environmental Protection and Energy 2014-2020', OJ [2014] C 200/1 [2014-2020 EEA Guidelines]; see further section III.B below.

${ }^{52}$ European Commission, 'Renewable Energy Progress Report' COM(2015) 293final, 15 June 2015, at 3.

${ }^{53}$ Commission Policy Brief 2014 (n 49), at 2. 
a low-carbon and energy-efficient economy beyond 2020: as part of its climate and energy goals for 2030, the EU has committed to a new target of at least $27 \%$ share of RE in its final energy consumption. ${ }^{54}$ This new ambition has triggered a (still on-going) review of the underpinning legislative framework, including a proposal put forward by the Commission in late November 2016 for a recast of the previously examined 2009 Renewable Energy Directive. ${ }^{55}$ While still under consideration, the proposed Directive would introduce significant changes vis-à-vis the still in force 2009 Renewable Energy Directive, of which two are worth mentioning here. First, the overall $2030 \mathrm{RE}$ target is binding at EU level and, unlike under the current Directive, it has not been translated into binding national targets allocated to each Member State. ${ }^{56}$ Second, the proposed Directive is more detailed in outlining the measures that may be taken by the Member States in order to ensure the collective attainment of the EU-wide target for renewable energy in 2030. Notably, in the case of green electricity, ${ }^{57}$ Member States may continue to implement support schemes subject to EU State aid rules, but a number of principles and specific conditions are further stipulated so as to facilitate a 'cost-effective', 'marketoriented' and 'Europeanised approach' in their design, as well as their 'gradual and partial opening to cross-border participation'. ${ }^{58}$ Again, this follows the harmonization and market integration spirit of the 2014-2020 EEA Guidelines and will be discussed in more depth in the next part. ${ }^{59}$

\section{COMPARING EU AND WTO APPROACHES TO GREEN ELECTRICITY SUPPORT}

\section{A. Different Approaches to Negative Integration}

The backbone of EU State aid rules is to be found among the common rules on competition, taxation and approximation of laws in Articles 107-109 of the Treaty on the Functioning of the European Union (TFEU). ${ }^{60}$ These provisions, which have remained largely unchanged since their incorporation into the original Treaty of Rome, ${ }^{61}$ establish a centralised system of State aid control that rests on a sensitive balance between negative and positive integration. With regards to negative integration, Article 107(1) TFEU lays down a general prohibition on 'any aid granted by a Member State or through State resources in any form whatsoever which distorts or threatens to distort competition by favouring certain undertakings or the production of certain goods ... in so far as it

\footnotetext{
${ }^{54}$ European Commission, 'Communication on a Policy Framework for Climate and Energy in the period from 2020 to 2030’ COM(2014) 15 final, 22 January 2014 [Communication Climate and Energy 2030], at 6; and European Council, 'Conclusions - Brussels, 23-24 October 2014' (EUCO 169/14), 24 October 2014, at 5 .

${ }^{55}$ European Commission, 'Proposal for a Directive of the European Parliament and of the Council' COM(2016) 767 final/2, 23 February 2017 [2016 Proposed RE Directive].

${ }^{56} \mathrm{Ibid}$, Article 3 (1)-(2). Article 3(3) establishes the 2020 national RE targets as baseline, whereby Member States cannot go below them from 2021 onwards.

${ }^{57}$ See also, ibid, Art 23 on mainstreaming renewable energy in the heating and cooling sector (requiring MS to achieve an annual increase of at least 1 percentage point every year in the share of renewable energy in the heating and cooling supply, and outlining a number of measures to implement this objective) and Art 25 on mainstreaming renewable energy in the transport sector (stipulating minimum shares of energy from advanced biofuels and other biofuels and biogas produced from feedstock listed in Annex IX in the supply of transport fuels, at least equal to $1.5 \%$ in 2021 and increasing up to at least $6.8 \%$ in 2030 following the trajectory set out in part B of Annex X).

${ }^{58}$ Ibid., Arts 4-5; and 'Explanatory Memorandum', at 21.

${ }^{59}$ See section III.B below.

60 Treaty on the Functioning of the European Union - Consolidated Version (TFEU), [2012] OJ C326/47.

61 Treaty establishing the European Economic Community, signed on 25 March 1957, Arts 92-94.
} 
affects trade between Member States'. According to the case law of the EU Court of Justice (CJEU), four cumulative conditions have to be met for a government measure to fall under Article 107(1) prohibition: (i) it must confer an economic advantage on the recipient that it would not have received under normal market conditions; (ii) it must entail an actual or potential use of State resources; (iii) it must be selective, by favouring certain undertakings or the production of certain goods; (iv) it must be liable to distort competition and affect intra-EU trade. ${ }^{62}$ In principle, this general prohibition equally applies to renewable energy support schemes, since the purpose of State aid is irrelevant under Article 107(1) TFEU.

In comparison, WTO rules on subsidies are far more detailed but similarly follow the logic of negative integration in constraining trade-distortive governmental support. In doing so, WTO subsidy law shares a number of basic requirements with EU State aid law. This is most noticeable when one looks at the three cumulative conditions for a given measure to qualify as a 'subsidy' for the purposes of applying the SCM Agreement: (i) it must be a financial contribution (or income/price support) by a government or public body ${ }^{63}$ (or by a private body 'entrusted' or 'directed' by a government); ${ }^{64}$ (ii) it must confer a benefit (i.e., analogous to 'economic advantage' under EU State aid law); ${ }^{65}$ (iii) it must be specific (i.e., analogous to the 'selectivity' condition under EU State aid law). ${ }^{66}$ But as will be shown next, the scope and depth of negative integration in these two regulatory regimes fundamentally differs in both substantive and procedural terms, with the overall result that WTO subsidy disciplines are less constraining on green policy space.

Admittedly, this does not hold true for every element of the notion of 'subsidy' under WTO law which, in some respects, is broader than that of 'State aid' under EU law. ${ }^{67}$ Notably, while the form of the aid is not material under Article 107(1) TFEU (referring to 'any form whatsoever'), ${ }^{68}$ only measures that are both imputable to a Member State and financed directly or indirectly through 'State resources' may be regarded as State aid..$^{69}$ In other words, there is a requirement of a 'charge on the public account' (or cost to government) for a measure to constitute State aid under EU law. ${ }^{70}$ Interestingly, in PreussenElektra, the Court held that an obligation on private electricity suppliers to purchase electricity produced from renewable energy sources at fixed (above-market) minimum prices (thus, conferring an economic advantage) did not constitute State aid, because it did 'not involve any direct or indirect transfer of State resources to undertakings which produce that type of electricity. ${ }^{, 11}$ By contrast, no similar

\footnotetext{
${ }^{62}$ See further K. Bacon, European Union Law of State Aid (2 ${ }^{\text {nd }}$ edition, Oxford University Press 2013), at 2087.

${ }^{63}$ SCM Agreement, Arts 1.1(a)(1)(i)-(iii) and 1.1(a)(2).

${ }^{64}$ Ibid, Art 1.1(a)(1)(iv).

${ }^{65}$ Ibid, Art 1.1(b).

${ }^{66}$ Ibid, Arts 1.2 and 2.

${ }^{67}$ For a detailed comparative analysis, see L. Rubini, The Definition of Subsidy and State Aid: WTO and EC Law in Comparative Perspective (Oxford University Press 2009). In addition, WTO disciplines are clearly not confined to support measures that distort competition and trade within the EU, but more broadly apply to subsidies that affect international trade. For further discussion, see C-D. Ehlermann and M. Goyette, 'The Interface between EU State Aid Control and the WTO Disciplines on Subsidies' (2006) 4 European State Aid Law Quarterly 695, at 698-699 and 717.

${ }^{68} C f$ with Art 1.1(a)(1) SCM Agreement, providing an exhaustive but broad list of qualifying 'financial contributions'. For a discussion, see P. van den Bossche, The Law and Policy of the World Trade Organization, ( $3^{\text {rd }}$ edition, Cambridge University Press 2013), at 750-757.

${ }^{69}$ On this condition, see further Bacon (n 62), at 61-63.

${ }^{70}$ On this requirement, see further Ehlermann and Goyette (n 67), at 698-699.

${ }^{71}$ Case C-379/98 PreussenElektra [2001] ECR I-2099, paras 58-62.
} 
'cost to government' requirement exists under WTO law ${ }^{72}$ and the measure at issue in PreussenElektra could be arguably covered by the SCM Agreement as a financial contribution (i.e., purchase of goods) by a private body entrusted or directed by a government. ${ }^{73}$ While EU State aid law could thus be regarded as more lenient in this particular respect, it seems of limited relevance to our discussion which is mainly concerned with government-provided price-support mechanisms (FITs or premium tariffs) and fiscal and financial incentives (e.g., grants or preferential loans) in light of prevailing policy practice. ${ }^{74}$

A more significant difference for present purposes relates to the threshold requirement of 'benefit' for a government support measure to be subject to SCM disciplines, and the parallel 'economic advantage' condition under EU State aid law. In both systems, the existence of a benefit or economic advantage needs to be determined in relation to prevailing conditions in the marketplace. ${ }^{75}$ However, what is the relevant market for the benefit comparison under the SCM Agreement has become a more complex matter following the Appellate Body's report in Canada - Renewable Energy (2013). This complaint was brought by Japan and the EU against the local content requirements (LCRs) ${ }^{76}$ in the FIT programme through which the Canadian province of Ontario provided (inter alia) 20-year guaranteed prices for electricity produced by using wind or solar PV technology. The complainants argued that these LCRs violated several WTO provisions, including Article 3.1(b) and 3.2 of the SCM Agreement that forbid subsidies contingent upon the use of domestic over imported goods and are of most pertinence in the present context. ${ }^{77}$

In addressing this prohibited subsidy claim, the Appellate Body agreed that Ontario's FIT programme constituted a financial contribution by government in the form 'purchase of goods', ${ }^{78}$ but found that the Panel had erred in conducting the benefit analysis in the competitive wholesale electricity market as a whole (i.e., in the single market for all electricity, no matter how produced), when the relevant market should have been 'the competitive markets for wind- and solar PV-generated electricity, which are created by the government definition of the supply mix." ${ }^{79}$ This was because, according to the Appellate Body, the definition of the relevant market cannot stop at

\footnotetext{
72 WTO Appellate Body Report, Canada - Measures Affecting the Export of Civilian Aircraft, WT/DS70/AB/R, adopted 19 November 1999, [Canada - Aircraft (1999)], para 154, rejecting Canada's argument that 'cost to government' is one way of conceiving the existence of a 'benefit' under Art 1.1(b) SCM Agreement.

${ }^{73}$ SCM Agreement, Art 1.1(a)(1)(iii)-(iv).

${ }^{74}$ See section II above.

75 Appellate Body Report, Canada - Aircraft (1999) (n 72), para 157 and Art 14 SCM Agreement; Ehlermann and Goyette (n 67), at 700-701.

${ }^{76}$ Appellate Body Report, Canada - Renewable Energy (2013) (n 1), paras 1.4-1.7.

77 In addition, the complainants challenged the discriminatory LCRs in Ontario's FIT programme by invoking Article III:4 of the General Agreement on Tariffs and Trade (GATT) and Article 2.1 of the Agreement on Trade-Related Investment Measures (TRIMs). The Appellate Body found that Canada had violated these national treatment provisions, but an examination of these findings is beyond the scope of this article. For a detailed discussion see, among others, A. Darvies, 'The GATT Article III:8 Procurement Derogation and Canada - Renewable Energy' (2015) 18(3) Journal of International Economic Law 543; Charnovitz and Fischer (n 29), at 189-192; Cosbey and Mavroidis (n 2), 15-18.

${ }^{78}$ Art 1.1(a)1(iii) SCM Agreement. Pursuant to Art 14(d) SCM Agreement, it would confer a benefit if "the purchase is made for more than adequate remuneration" with the adequacy of remuneration being determined in relation to the "prevailing market conditions for the good or service in question in the country of purchase": Appellate Body Report, Canada - Renewable Energy (2013) (n 1), paras 5.128, 5.1595.160 and 5.165 .

${ }^{79}$ Ibid, para 5.178 .
} 
demand-side substitutability (as under EU State aid law) ${ }^{80}$ but should also consider supply-side substitutability. ${ }^{81}$ On the demand-side, the fact that electricity is physically identical regardless of how it is generated suggests a high-demand substitutability between electricity generated through different technologies ${ }^{82}$ and thus weights 'in favour of defining the relevant market as a single market for electricity generated from all sources of energy'. ${ }^{83}$ Yet for the Appellate Body, this was outweighed by supply-side factors indicating that 'windpower and solar PV producers of electricity cannot compete with other electricity producers because of differences in cost structures and operating costs' and, for as long as these differences remain so significant, 'markets for wind- and solar PV-generated electricity can only come into existence as a matter of government regulation. ${ }^{84}$ In other words, the government's choice of the electricity supply-mix is what 'creates markets for wind- and solar PV-generated electricity', but in the Appellate Body's view, 'this cannot in and of itself be considered as conferring a benefit within the meaning of Article 1.1(b) of the SCM Agreement. ${ }^{85}$ For the purpose of the benefit analysis, the relevant question was 'whether wind and solar PV electricity suppliers would have entered the wind- and solar PV-generated electricity markets absent the FIT Programme, not whether there would have entered the blended wholesale electricity market. ${ }^{86}$

This line of reasoning has generated an avalanche of mostly critical reactions in the literature on both legal and policy grounds, but it is not the place here to engage with them. ${ }^{87}$ The key implication for our purposes is that, by narrowing the relevant market within which appropriate benchmark prices are to be located for the benefit comparison to the 'competitive markets for wind- and solar PV-generated electricity' (rather than the 'competitive wholesale electricity market' as whole), ${ }^{88}$ the Appellate Body has made it harder for future complainants to demonstrate the existence of a benefit -and hence, that FIT programmes constitute a subsidy to which the SCM Agreement is applicable. ${ }^{89}$

\footnotetext{
${ }^{80}$ On this point see, L. Rubini, 'The Wide and the Narrow Gate: Benchmarking in the SCM Agreement after the Canada - Renewable Energy/FIT Ruling' (2015) 14(2) World Trade Review 211, at 219.

${ }^{81}$ Appellate Body Report, Canada - Renewable Energy (2013) (n 1), paras 5.171-5.172.

82 Ibid, para 5.170 .

${ }^{83}$ Ibid, para 5.178 .

${ }^{84} \mathrm{Ibid}$, paras 5.174-5.175.

${ }^{85}$ Ibid, para 5.175 (emphasis in original).

${ }^{86}$ Ibid, para 5.199.

${ }^{87}$ See in particular, Cosbey and Mavroidis (n 2), at 23-29; R. Pal, 'Has the Appellate Body Decision in Canada - Renewable Energy/Canada - Feed-in Tariff Program Opened the Door for Production Subsidies?' (2014) 17(1) Journal of International Economic Law 125; L. Rubini, 'The Good, the Bad, and the Ugly: Lessons on Methodology in Legal Analysis from the Recent WTO Litigation on Renewable Energy Subsidies' (2014) 48(5) Journal of World Trade 895. For a less critical stance, see J. Flett, 'Preserving the balance or compromise between trade and non-trade interests through a systemic and contextual interpretation and application of the W'TO Agreement, the GATT 1994 and the SCM Agreement - based on first principles and confirmed by a comparative consideration of EU State aid law' (Florence, 18-19 May 2015) [on file with the author]; and A. Kent and V. Jha, 'Keeping Up with Climate Change: the WTO's Evolutive Approach in Response to the Trade and Climate Change Conundrum' (2014) 15 Journal of World Trade Law and Investment 245.

${ }^{88}$ Appellate Body Report, Canada - Renewable Energy (2013) (n 1), para 5.190.

${ }^{89}$ That is, the narrower the market is, the more targeted the benchmarks for the benefit comparison are, and less likely we are to find there is a benefit and hence a subsidy. Conversely, had the 'competitive wholesale electricity market' as whole being chosen as the relevant market, there would have been little doubt that Ontario's FIT programme (and possibly most FITs) conferred a benefit (and hence constituted a subsidy), since it provided producers of wind- or solar PV-generated electricity with rates higher than the wholesale market rate for electricity in Ontario and ensured the entry of these producers into the Ontario electricity market when they would have otherwise not existed if left to operate under market conditions without government intervention. This was in fact the position of the dissenting panellist: WTO Panel
} 
Yet importantly, this does not mean it has made it impossible for FITs to be ever scrutinized under WTO subsidy law. While the Appellate Body was unable to complete the analysis in Canada - Renewable Energy (2013) due to insufficient factual findings on record, ${ }^{90}$ it did provide guidance on how to establish FITs confer a benefit in future cases (i.e., by looking at in-country price benchmarks; or adjusted out-of-country price benchmarks; or proxy construction), ${ }^{11}$ while equally hinted at how this situation may be avoided (i.e., by using 'price-discovery mechanisms' such as competitive bidding or negotiated prices so as to avoid over-compensation). ${ }^{92}$ Hence, the Appellate Body's approach to the benefit analysis in Canada - Renewable Energy (2013) offers some flexibility by creating a partial 'carve-out' - even if not a full 'safe haven'- for FIT programmes from WTO subsidy disciplines. ${ }^{93}$ Nevertheless, this ruling is without consequences for other popular government incentives to green electricity that are likely to face full scrutiny under WTO subsidy rules. This is because government (non-repayable) grants and preferential loans to green technology manufacturers are clearly financial contributions ${ }^{94}$ conferring a benefit, ${ }^{95}$ and often their granting is limited (in law or in fact) to 'certain enterprises'. ${ }^{96}$ But it is important to underline that, at this stage of subsidy definition, we are only dealing with the preliminary question of whether a given form of government support to renewable energy is or not subject to SCM disciplines, and not with the subsequent question of whether such a measure is or not compatible with that agreement.

In this regard, WTO subsidy rules appear less strict than EU State aid law in one critical aspect: how determinant are the effects of government support for the compatibility question. Here, the threshold under Article 107(1) TFEU is seemingly low: to be prohibited, selective State aid needs only to 'be liable' to affect competition and intra-EU trade, and there is no requirement that this potential effect be significant or substantial. ${ }^{97}$ In other words, any State measure that provides selective aid through public resources is, in principle, deemed incompatible with the EU internal market, with no

Report, Canada - Measures relating to the Feed-in Tariff Program, W'T/DS412/DS426/R, adopted (as modified) 24 May 2013, paras 9.1-9.23.

90 Appellate Body Report, Canada - Renewable Energy (2013) (n 1), para 5.234-5.245, noting in particular the overall finding that "[...] RES prices for wind generation contracts awarded through competitive bidding may qualify as benchmarks for a benefit comparison and seem to suggest that benefit may exist in the case of FIT wind-power generation contracts. We conclude, however, that such evidence neither sufficiently debated before the Panel, nor before us. Moreover, the Panel did not make factual findings on this evidence that would assist us in completing the analysis." (emphasis added)

${ }^{91}$ Appellate Body Report, Canada - Renewable Energy (2013) (n 1), para 5.227.

${ }^{92}$ Ibid, paras 5.228 and 5.233, noting that such price discovery mechanisms would 'ensure that the price paid by the government is lowest possible price offered by a willing contract supplier' (emphasis added) and hence would help avoiding 'more than adequate compensation' within the meaning of Art 14(d) SCM Agreement; for further discussion, see Charnovitz and Fischer (n 30), at 197-198.

${ }^{93}$ For a similar view, see Cosbey and Mavroidis (n 2), at 28-29; and L. A. Cosbey and L. Rubini, 'Does it FIT? An Assessment of the Effectiveness of Renewable Energy Measures and of the Implications of the Canada - Renewable Energy/FIT Disputes' (International Centre for Trade and Sustainable Development/World Economic Forum, December 2013), at 4-8, http://e15initiative.org/publications/does-it-fit-an-assessment-of-the-effectiveness-of-renewable-energymeasures-and-of-the-implications-of-the-canada-renewable-energyfit-disputes/.

${ }^{94}$ SCM Agreement, Art 1.1(a)(1)(i).

95 Ibid, Art 14(b).

${ }^{96} \mathrm{Ibid}$, Arts 2.1(a) and 2.2 on how de jure enterprise/industry/regional specificity may be established and Art 2.1(c) on how de facto enterprise/industry/regional specificity may be established. As this does not differ fundamentally from the notion of 'selectivity' under EU State aid law, it will not be further discussed here: for a comparison, see Ehlermann and Goyette (n 67), at 701-704.

${ }^{97}$ On this point see J. Flett, A. C. Jessen and K. Talaber-Ritz, 'The Relationship between WTO Subsidies Law and EC State Aid Law' in EC State Aid Law (Kluwer Law International 2008), at 447-449. 
need to prove a actual distortive effect on competition or intra-EU trade. ${ }^{98}$ Conversely, under WTO law, trade-distortive effects are not generally presumed but only in two specific cases: namely, export subsidies (i.e., those contingent upon export performance) and import-substitution subsidies (i.e., those contingent upon the use of domestic over imported goods). These are both expressly aimed at distorting trade and investment flows, and thus prohibited outright. ${ }^{99}$ All other specific subsidies are just actionable under the SCM Agreement, which means they are only WTO-incompatible to the extent it is demonstrated that they cause actual 'adverse effects' to the import-competing (in the form of 'material injury') ${ }^{100}$ or export-competing interests (in the form of 'serious prejudice') ${ }^{101}$ of another W'TO member.

To illustrate the importance of this distinction, it is useful to return to the Canada - Renewable Energy (2013) case. There is little doubt that the Canadian FIT programme, if held to be a subsidy under the SCM Agreement, would have been sanctioned as a prohibited import-substitution subsidy (Article 3.1(b) SCM) because the 20-year guaranteed rate for wind- and solar PV-generated electricity was made conditional upon using a certain percentage of Ontario-produced RE generation equipment (e.g. Ontariomade wind turbines or solar panels) in developing and constructing generation facilities. But this result would have been largely immaterial (other than for the remedy issue), ${ }^{102}$ given that these local content requirements (LCRs) were already found to violate the core national treatment obligations under other WTO agreements. ${ }^{103}$ Yet importantly, this should not be mislabelled as a direct conflict between international trade and climate change mitigation regimes: LCRs are primarily tools of industrial policy (in casu, to stimulate local investment in and manufacturing of RE generation equipment), ${ }^{104}$ and there is no clear evidence that attaching a LCR condition to FITs brings any added environmental benefits. ${ }^{105}$ Therefore, from a trade/environment perspective, the critical

\footnotetext{
${ }^{98}$ See further, Bacon (n 62), at 12-13 and 82-87.

${ }^{99}$ SCM Agreement, Art 3. For a more detailed examination, see van den Bossche (n 68), at 770-776.

100 SCM Agreement, Arts 5(a) and 15, referring to 'material injury', or threat thereof, to the domestic industry of another member producing the like product.

${ }^{101} \mathrm{Ibid}$, Arts 5(c) and 6.3, referring to 'serious prejudice', or threat thereof, to the interests of another member, including by 'displacing or impeding' imports of a like product into the market of the subsidising member, or by 'displacing or impeding' exports of a like product into the market of a third country, or by resulting in 'significant' price undercutting, price suppression, price depression or lost of sales. For a more detailed examination, see van den Bossche (n 68), at 779-794.

102 The SCM Agreement provides for special remedies which, in the case of prohibited subsidies, is their removal 'without delay' generally meaning three months (Article 4.7).

103 That is, Articles III:4 GATT and 2.1 TRIMs: see Panel Report, Canada - Renewable Energy (2013) (n 89), para 7.167 and Appellate Body Report, Canada - Renewable Energy (2013), para 5. 85. Similarly, see W'TO Appellate Body Report, India - Certain Measures Relating to Solar Cells and Solar Modules, WT/DS456/AB/R, adopted 14 October 2016 [India - Solar Cells (2016)], where LCRs attached to India's feed-in tariffs scheme for solar power producers were also found inconsistent with these WTO provisions.

104 Panel Report in Canada - Renewable Energy (2013) (n 89), para 7.216.

105 In the short-run, importing more (cheaper) foreign RE technology rather than imposing (costly) LCRs would result in an environmentally superior outcome. But there is a long-run theoretical argument in favour of 'green' industrial policy, whereby supporting local green infant-industries would allow them to mature and become competitive innovators in the green technology space, and thereby force down global prices of RE generation equipment: IISD/UNEP Handbook 2014 (n 13), at 95. However, partly due to their novel character, there is no evidence that LCRs can accomplish this long-term environmental goal, and moreover evidence is flawed on LCR effectiveness in achieving their most immediate industrial policy objective: see Cosbey and Rubini (n 93), at 2; J-C. Kuntze and T. Moerenhout, 'Local Content Requirements and the Renewable Energy Industry - A Good Match?' (International Center for Trade and Sustainable Development/Global Green Growth Institute, May 2013), https://pdfs.semanticscholar.org/6872/7a8d62a9722b28a250bef0470aeb847108f9.pdf. Another argument in favour of LCRs is the 'political feasibility' rationale for RE technology localisation, S. Z. Bigdeli, 'Clash of Rationalities: The Trade and Environment Debate in Light of WTO Disputes over Green Industrial
} 
question is whether FIT programmes without LCRs would run afoul of WTO subsidy law.

In answering this question, the most relevant provision is Article 6.3(a) SCM Agreement, which requires a demonstration that 'the effect of the subsidy [in casu, a FIT without LCRs] is to displace or impede the imports of a like product [in casu, brown electricity or electricity from renewable energy sources not covered by the FIT] of another Member into the market of the subsiding Member.' Here, unlike under EU State aid law, the threshold is not low since there needs to be a 'genuine and substantial relationship of cause and effect' between the subsidy and the current (or imminent) ${ }^{106}$ trade distortion. ${ }^{107}$ But most fundamentally, for a FIT scheme to cause such adverse effects and be found SCM-incompatible, there must exist trade flows or opportunities in electricity between the FIT-providing W'TO member and another WTO member -if there is no trade, there can simply be no actual or potential trade-distortive effects. However, as mentioned earlier, ${ }^{108}$ electricity is sparsely traded internationally: for instance, even between neighbouring countries such as the Canada and the US with interconnected electrical grids, imports of electricity from Canada into the US only amounted to $1.6 \%$ of its overall power consumption in $2014 .{ }^{109}$ Similarly, on the overall EU-28 level, net imports of electricity in 2015 were less than 1\% of the electricity consumption by end-users. ${ }^{110}$ In fact, it is highly doubtful that the EU and Japan would have challenged Ontario's FIT programme in the W'TO absent the LCRs, given they have no electricity trade with Canada. ${ }^{111}$ While not impossible, the risk that non-discriminatory FITs are in breach of WTO subsidy law is limited inasmuch as cross-border electricity trade, which is reassuring for the mutual supportiveness between WTO law and climate change law.

By the same token, the risk of WTO-inconsistency is relatively higher for government support measures to investment and manufacturing of RE generation equipment (say, solar PV modules) which, unlike electricity itself, are easily and extensively traded globally. Whereas a conclusive assessment can only be made based on a fact-intense enquiry into the economic effects of the specific subsidy at issue, a 'serious prejudice' scenario is not so difficult to imagine: that is, lower-cost subsidized solar PV modules from country A may 'displace' imports of solar PV modules from country B (Article 6.3(a) SCM), or result in 'significant lost sales' of country B's solar PV modules in a third-country market or the world market (Article 6.3(c) SCM). ${ }^{112}$ Similarly, it is possible that lower-cost subsidized solar PV modules from country A are instead

Policy' (2014) 6(1) Trade, Law and Development 177, at 195-208. Cf with Howse (n 2), at 1; and Cosbey and Mavroidis (n 2), at 33.

106 SCM Agreement, Art 5(c), footnote 13 clarifies that the term 'serious prejudice' also includes 'threat of serious prejudice' (i.e., prejudice that does not yet exist but is imminent such that it would materialise in the near future): see van den Bossche (n 68), at 795.

107 WTO Appellate Body Report, EC and Certain Member States - Measures affecting Trade in Large Civil Aircraft, WT/DS/316/AB/R, adopted 1 June 2011, para 1232; WTO Appellate Body Report, United States Measures affecting Trade in Large Civil Aircraft (2 $2^{\text {nd }}$ complaint), WT/DS353/AB/R, adopted 23 March 2012, para 914; see van den Bossche (n 68), at 796.

108 See section II.A above.

109 US Energy Information Administration, 'US-Canada Electricity Trade Increases' (9 July 2015), http://www.eia.gov/todayinenergy/detail.php?id=21992.

${ }^{110}$ However, there is quite a difference across various EU Member States. While Lithuania, Luxembourg, Hungary and Malta are net importers for $77 \%, 90 \%, 38 \%$ and $50 \%$ respectively, Bulgaria, the Czech Republic and Sweden are net exporters for $37 \%, 23 \%$ and $18 \%$ respectively. Only disconnected islands show no trade of electricity (Cyprus and Iceland): see, Eurostat, 'Electricity and Heat Statistics' (June 2017), http://ec.europa.eu/eurostat/statistics-explained/index.php/Electricity and heat statistics.

${ }^{111}$ Charnovitz and Fischer (n 30), at 185.

${ }^{112}$ For the purpose of the argument, it is safe to assume that solar PV modules from country A and B are 'like' (competitive) products. 
exported to country B and cause 'material injury' to its domestic solar PV industry (Article 5(a) SCM). ${ }^{113}$ In this sense, a tension between WTO law and climate change law appears most evident: wouldn't it make sense from an environmental (and indeed economic) perspective to simply allow country A to continue exporting its cheap solar PV panels to country B and rest of the world? ${ }^{114}$

Aside from these important substantive differences, the aspect on which EU State aid law and WTO subsidy law most crucially differ is in terms of monitoring and enforcement mechanisms. In the EU's context, the general prohibition under Article 107(1) TFEU is backed up by sophisticated procedures for ex ante and expost centralised control by a supranational agent -the European Commission. ${ }^{115}$ As a general rule, Member States are required to notify their planned State aid measures (including material alterations to existing aid) to the Commission, which has exclusive competence for assessing their compatibility with the internal market, and any such aid can only be put into effect after obtaining the Commission's approval. ${ }^{116}$ The implementation of unauthorised State aid is therefore unlawful and the Commission is empowered to suspend the relevant aid measure and order the full retroactive repayment of any aid already granted. ${ }^{117}$ Similarly, the Commission may open a formal investigation procedure for any authorised State aid used in contravention of its approval decision (misused aid), and has similar powers of suspension and recovery as in the case of unlawful aid. Moreover, any existing aid is subject to regular reporting and continuous review by the Commission. ${ }^{118}$

These extensive powers of the European Commission in the field of State aid control are by no means matched by the surveillance role of the WTO Committee on Subsidies and Countervailing Measures, which is composed of governmental representatives. ${ }^{119}$ First, the SCM Agreement only requires WTO members to notify (by 30 June of each year) specific subsidies that are already granted or maintained within their territories, ${ }^{120}$ and thus there is no scrutiny and authorisation prior to implementation. This means that 'policy space' to boost renewable energy is not a priori constrained under the SCM Agreement, but may only be expost when and if a given support measure is challenged in the WTO dispute settlement system. Even so, the compliance record with the notification requirement under the SCM Agreement has been far from impressive: according to the WTO Secretariat, over the period 1995-2013, the number of WTO members that have complied with this procedural obligation (either by notifying specific

\footnotetext{
${ }_{113}$ An apposite practical example here would be subsidized solar panels exported from China to the EU and US, which were subject to the anti-dumping and countervailing investigations discussed below (see $\mathrm{n}$ 121).

114 On this point, with particular reference to China, see K. Kulovesi, 'International Trade Disputes on Renewable Energy: testing the Ground for Mutual Supportiveness between WTO Law and Climate Change Law' (2014) 23(3) Review of European Community and International Environmental Law 324, at 351-2. For a more nuanced position, see IISD/UNEP Handbook 2014 (n 14), at 106.

115 Art 108 TFEU; and Council Regulation (EU) No 2015/1589 of 13 July 2015 laying down detailed rules for the application of Article 108 TFEU, OJ [2015] L248/9.

116 Art 108(3) TFEU. One exception to this general rule is provided in: Commission Regulation (EU) No 1407/2013 on the application of Articles 107 and 108 TFEU to de minimis aid, OJ [2013] L352/1. For all covered sectors (Art 1), State aid may be granted up to a ceiling $€ 200,000$ per single undertaking over any period of three fiscal years, or $€ 100,000$ in the road transport sector (Art 3). Any such de minimis aid is deemed not to distort competition nor affect intra-EU trade, and thus does not meet the criteria of Art 107(1) TFEU and does not need to be notified under Art 108(3) TFEU.

${ }^{117}$ By contrast WTO remedies are prospective, probably reflecting the idea that the system is designed primarily to protect current and future trade flows: Flett (n 97), at 449.

${ }^{118}$ For a more detailed examination, see Bacon (n 62), chapter 18.

119 SCM Agreement, Art 24.1.

$120 \mathrm{Ibid}$, Arts 25.1 and 25.2.
} 
subsidies or submitting a nil notification) has remained relatively stable, whereas the number of WTO members that have failed to do so has risen sharply as membership has increased. ${ }^{121}$ To take the most recent data, in year 2016, 33 members notified subsidy measures in place and 15 notified that they not maintain any notifiable specific subsidies, ${ }^{122}$ meaning that the vast majority of the WTO membership $(106 / 136)^{123}$ did not observe the notification requirement. Second, the review of notified subsidies in the SCM Committee does not amount to a compatibility assessment, but just affords WTO members the opportunity to request additional information and exchange views on the subsidy notifications. ${ }^{124}$

Finally, unlike in the EU context, the enforcement of W'TO subsidy rules is not systematic and fully centralised, but only if a WTO member decides to bring a complaint in the WTO dispute settlement system. ${ }^{125}$ To date, out of the 116 cases brought under the SCM Agreement, only 6 have concerned renewable energy and all of them allegedly discriminatory (local content-contingent) measures. ${ }^{126}$ Thus far, the WTO dispute settlement organs have only ruled in one instance (Canada - Renewable Energy (2013)), while other cases are still at panel proceedings or (formally) pending at consultation stage. ${ }^{127}$ Further, in the case of subsidised imports causing 'material injury', the SCM Agreement gives W'TO members the choice to respond multilaterally through the W'TO dispute settlement system or, in the alternative, to take unilateral remedial action: namely, the imposition of countervailing duties $(\mathrm{CVDs})^{128}$-something which is not permitted under EU State aid law. Government support to manufacturers of green technology products has been mainly challenged through this national trade remedy track, ${ }^{129}$ with well-known examples being the parallel countervailing and anti-dumping duty investigations ${ }^{130}$ conducted by both the EU and the US on (allegedly) subsidised imports

${ }^{121}$ WTO Committee on Subsidies and Countervailing Measures, Notification Requirements under the Agreement on Subsidies and Countervailing Measures - Background Note by the Secretariat' (G/SCM/W/546/Rev.6), dated 14 April 2015, at 3.

${ }_{122}$ WTO Committee on Subsidies and Countervailing Measures, 'Report 2016' (G/L/1157), dated 31 October 2016, at 2. This represents a limited improvement from the previous year, when the numbers were 21 members and 6 members respectively: WTO Committee on Subsidies and Countervailing Measures, 'Report 2015’ (G/L/1133), dated 29 October 2015, at 2.

${ }^{123}$ For this purpose, the EU and its 28 Member States are counted as a single member.

124 Article 25.7 SCM Agreement; see e.g. review of 2015 and 2013 subsidy notifications in: WTO Committee on Subsidies and Countervailing Measures, 'Minutes of the Special Meeting held on 27 October 2015' (G/SCM/M/94), dated 2 February 2016.

125 SCM Agreement, Arts 4 and 7 on multilateral remedies for prohibited and actionable subsidies respectively.

126 Note that, in the India - Solar Cells (2016) dispute (n 103), the initial US claims under the SCM Agreement were later withdrawn and thus not counted here.

${ }^{127}$ In addition to the joint complaints in Canada - Renewable Energy (2013) discussed above (n 1): United States - Certain Measures Relating to the Renewable Energy Sector, Request for the Establishment of a Panel by India (WT/DS510/2) dated 24 January 2017; European Union and Certain Member States - Certain Measures on the Importation and Marketing of Biodiesel and Measures Supporting the Biodiesel Industry, Request for Consultations by Argentina (WT/DS459/1) dated 23 May 2013; European Union and certain Member States - Certain Measures Affecting the Renewable Energy Generation Sector, Request for Consultations by China (WT/DS452/1) dated 5 November 2012; China - Measures concerning Wind Power Equipment, Request for Consultations by the United States (WT/DS419/1) dated 6 January 2011.

${ }_{128}$ SCM Agreement, Part V on the imposition of CVDs as a unilateral remedy to offset the effects of a specific subsidy in the domestic market of the importing WTO member.

${ }^{129}$ IISD/UNEP Handbook 2014 (n 13), at 105.

130 The conduct of anti-dumping and countervailing duty investigations are very similar in procedural terms, but differ on the substantive conditions to be established for the imposition of trade remedy measures. Under the Anti-Dumping Agreement, three basic requirements need to be met: (i) there are dumped imports (instead of subsidized imports); (ii) there is material injury (or threat thereof) to the 
of solar panels and their components from China. ${ }^{131}$ In fact, according to a global survey conducted by the United Nations Conference on Trade and Development (UNCTAD), the number of anti-dumping and countervailing duty cases in the renewable energy sector 'far outnumbers the number of [renewable energy] disputes that have arrived at the WTO'. ${ }^{132}$ While only covering the period 2008-early 2014, the survey already recorded a total of 41 trade remedy investigations initiated in the renewable energy sector, with almost half of these cases (18) targeting solar technology products and another seven cases involving wind technology products. ${ }^{133}$ This overview of WTO dispute settlement and unilateral practice brings an important question to the fore: which international trade rules are actually constraining policy space to support green energy as a means to combat climate change? Is the multilateral track under the SCM Agreement the main problem, or rather unilateral action under WTO trade remedy rules (including also the Anti-Dumping Agreement)?

\section{B. EU Distinctiveness: A Two-Track Justification for State Aid to Green Energy}

The preceding comparative analysis has revealed that, while EU State aid law and WTO subsidy law share some basic tenets of negative integration, the former is much more constraining on government support action in both substantive and procedural terms. This is so, in particular, because the general prohibition on State aid under Article 107(1) TFEU is broader with no need to prove actual trade-distortive effects, and is backed up by the singularly powerful and centralised control of the European Commission. In turn, this goes a long way in explaining why the EU's approach to State aid control is fundamentally distinct for its positive legal dimension. That is, the wide prohibition is counterbalanced by a relatively extensive system of justifications, ${ }^{134}$ which positively defines the terms and conditions under which State aid is deemed legitimate and permitted. The legal basis for such a positive justification is found in Articles 107(2) and (3) TFEU, which qualify the general prohibition by introducing a number of derogations for categories of State aid that are sheltered mainly in light of their purpose. These are deemed compatible with the internal market and hence admissible, ${ }^{135}$ either automatically (paragraph 2) ${ }^{136}$ or in most cases at the Commission's discretion (paragraph 3). ${ }^{137}$ Of most relevance to our purposes is Article 107(3) TFEU, whose key underlying principle is that decisions by the Commission on the compatibility of State aid must weigh its positive impact in reaching a set of legitimate objectives against any negative tradedistortive effects. However, the TFEU defines these objectives in rather vague terms:

domestic industry producing the like product; and (iii) there is a genuine and substantial causal link between the dumped imports and the injury. See further, van den Bossche (n 68), Chapter 11.

${ }^{131}$ For a discussion, see Kulovesi (n 114), at 348-341; and Shadikhodjaev (n 2), at 488-493.

132 United Nations Conference on Trade and Development, Trade Remedies: Targeting the Renewable Energy Sector (2014), at 13.

133 Ibid., at 3-4. The other 16 cases instead concerned biofuels (i.e., biodiesel and ethanol).

134 Note that the introductory words of Art 107(1) TFEU ('save as otherwise provided in the Treaties') make clear that the prohibition is not absolute.

135 In addition, the Council acting on a proposal from the Commission may to introduce further derogations if needed: Art 107(3)(d) TFEU.

136 Automatic compatibility includes State aid: having a social character (Art 107(2)(a)); necessary to make good the damage caused by natural disasters or exceptional occurrences (Art 107(2)(b)); and granted to the economy of certain areas of Germany affected by the cold war division (Art 107(2)(c)). In these cases, the Commission has no discretion as to whether or not to authorize the aid, but merely ascertains that the conditions set out in Art 107(2) TFEU are fulfilled. See further, Bacon (n 62), at 95-100.

${ }^{137}$ Discretionary compatibility includes: cohesion aid (Art 107(3)(a)); aid to important projects of common European interest or to remedy a serious disturbance in the economy of a Member State (Art 107(3)(b)); and aid to promote culture and heritage conservation (Art 107(3)(d)). See further, Bacon (n 62), at 100-113. 
glaring examples are references to 'aid to important projects of common European interest' (Article 107(3)(b)), and to 'aid to facilitate the development of certain economic activities or of certain economic areas, where such aid does not adversely affect trading conditions to an extent contrary to the common interest' (Article 107(3)(c) TFEU). Similarly, there is not much guidance on how to balance any such objective of 'common interest' against the potentially trade-distortive effects of the State aid in question. As Blauberger aptly notes, this ambiguity in EU treaty law provides the Commission with wide discretion and enabled it to 'act as a supranational entrepreneur, not only in enforcing the prohibition of distortive State aid, but also developing its own vision of 'good' State aid policy ... and thus created positive integration from above. ${ }^{138}$

In our particular case, there is little doubt that environmental protection in general, and in particular combating climate change and promoting the development of renewable energy, are objectives of 'common interest' for the $\mathrm{EU}^{139}$ which, in certain circumstances, may justify the granting of State aid in spite of any potential distortion on competition and/or intra-EU trade. That being so, a complex system of justifications for 'good' environmental State aid has been developed by the European Commission in a hybrid form, using a combination of both hard-law and soft-law instruments which have been recently reviewed following the 'State Aid Modernisation' process initiated in May 2012. ${ }^{140}$ More specifically, there is presently a two-track approach for sheltering renewable energy support measures from the basic prohibition in Article 107(1) TFEU: either under (i) the general 2014 General Block Exemption (GBE) Regulation, ${ }^{141}$ which automatically authorizes State aid under certain conditions without prior notification and individual scrutiny by the Commission; ${ }^{142}$ or if not eligible under this Regulation, under (ii) the specific 2014-2020 Guidelines on State Aid for Environmental Protection and Energy, ${ }^{143}$ which set out the principles and criteria against which the Commission assesses the compatibility of notified State aid and authorizes it on a case-by-case basis.

With regards to the first track, the 2014 GBE Regulation significantly extends the margins for Member States to grant aid without prior notification, in an attempt to focus ex-ante compatibility assessment by the Commission only on cases with the biggest potential to distort competition and intra-EU trade. ${ }^{144}$ However, it is important to highlight that the 2014 GBE Regulation does not apply to any State aid 'to export-related activities towards third countries or Member States', nor 'contingent upon the use of domestic over imported goods ${ }^{145}$-in other words, the category of prohibited subsidies under WTO law finds no legal shelter under the Regulation. Otherwise, the scope of the

\footnotetext{
${ }^{138}$ M. Blauberger, 'From Negative to Positive Integration? European State Aid Control through Soft and Hard Law' (2008) Max Planck Institute for the Study of Societies Discussion Paper 08/04, at 3 and 5, http://www.mpifg.de/pu/mpifg dp/dp08-4.pdf.

139 See, inter alia, Arts 191 and 194(1)(d) TFEU; see also Communication Energy 2020 (n 37) and Communication Climate and Energy 2030 (n 54).

${ }^{140}$ For more information: http://ec.europa.eu/competition/state aid/modernisation/index en.html.

141 Commission Regulation (EU) No 651/2014 of 17 June 2014 declaring certain categories of aid compatible with the internal market in the application of Articles 107 and 108 TFEU, OJ [2014] L187/1 [2014 GBE Regulation]. This replaced: Commission Regulation (EC) No 800/2008 declaring certain categories of aid compatible with the common market in application of Articles 87 and 88 of the Treaty, OJ [2008] L214/3 [2008 GBE Regulation].

1422014 GBE Regulation (n 141), Preamble, para 6.

143 See n 51 above.

144 European Commission, 'Memo - State Aid: Commission adopts new General Block Exemption Regulation' (14/369), dated 21 May 2014 [Commission Memo 2014], at 2, estimating that “3/4 of today's aid measures and about 2/3 of total aid amounts granted by Member States could be covered by the new GBER."

1452014 GBE Regulation (n 141), Arts 1(2)(c) and (d); similarly, 2008 GBE Regulation (n 141), Arts 2(a) and (b).
} 
current Regulation has been considerably broadened vis-à-vis its predecessor: it does not only cover 'investment aid' ${ }^{146}$ for the production of energy from renewable energy resources,${ }^{147}$ but also 'operating aid' ${ }^{148}$ for the production of electricity from renewable energy resources and of energy from renewable energy resources in small-scale installations. ${ }^{149}$ These RE support measures must, in turn, meet a number of general ${ }^{150}$ and category-specific conditions in order to be block exempted under the Regulation, which are briefly outlined next.

RE investment aid needs to be below the specified notification threshold of $€ 15$ million per undertaking per investment project, ${ }^{151}$ which implies a remarkable increase vis-à-vis the 2008 GBE Regulation (i.e., €7.5 million per undertaking per investment project). ${ }^{152}$ In addition, it can only be granted to new installations and shall be independent from output, ${ }^{153}$ as well as within the specified maximum aid intensities: 30 $45 \%, 55 \%$ and $65 \%$ of eligible costs ${ }^{154}$ respectively for large, medium-sized and small enterprises. ${ }^{155}$ However, this may go up to $100 \%$ of eligible costs, if the aid is granted in a competitive bidding process on the basis of clear, transparent and non-discriminatory criteria. ${ }^{156}$ As a general rule, operating aid to the green electricity production ought to be granted through such a competitive bidding process open to all green electricity generators on a non-discriminatory basis, ${ }^{157}$ in which case the notification threshold is set at a total of $€ 150$ million per year. ${ }^{158}$ As will be seen below, this competitive allocation of public support is in line with the Commission's push towards the gradual integration of matured RE technologies into the internal electricity market in the 2014-2020 EEA Guidelines. Nonetheless, Member States may limit the bidding process to specific RE technologies under certain conditions (e.g., if necessary to achieve diversification or secure grid stability). ${ }^{159}$ A special exemption is made for small-scale installations producing electricity from renewables, whereby operation aid may be granted in the absence of a competitive tendering process but may not exceed $€ 15$ million per undertaking. ${ }^{160}$

The above-indicated thresholds on both the amount and intensity of renewable energy aid are said to be derived from the 'Commission's market experience and

\footnotetext{
146 Usually referring to one-off aid measures covering upfront capital costs of investing in the production of energy from renewable energy sources (e.g., grants and preferential loans): Commission WD 2013 (n 49), at 11.

147 Defined as 'renewable non-fossil energy sources': wind, solar, aerothermal, geothermal, hydrothermal and ocean energy, hydropower, biomass, landfill gas, sewage treatment plant gas and biogases: 2014 GBE Regulation (n 141), Art 2 (110).

148 Usually referring to aid measures covering production-based costs of renewable energy generation (e.g., price-support instruments): see, Commission WD 2013 (n 49), at 11.

1492014 GBE Regulation (n 141), Arts 41-43. Cf. 2008 GBE Regulation (n 141), Art 23, covering only investment aid for the promotion of energy from renewable energy sources.

${ }^{150}$ E.g., on 'transparent aid': 2014 GBE Regulation (n 141), Art 5.

${ }^{151} \mathrm{Ibid}$, Art 4(1)(s).

1522008 GBE Regulation (n 141), Art 6(1)(b).

1532014 GBE Regulation (n 141), Art 41(5).

$154 \mathrm{Ibid}$, Art 41(6), the are the extra investment costs to promote the production of energy from renewable sources.

${ }^{155} \mathrm{Ibid}$, Arts 41(7) and (8). These maximum aid intensities are roughly the same as those found under the former 2008 GBE Regulation (n 141), Art 23(2).

1562014 GBE Regulation (n 141), Art 41(10).

1572014 GBE Regulation (n 141), Art 42(2); see also providing for flexibility for Member States to limit the bidding process to specific RE technologies and exempting small-scale installations from the bidding process.

158 Ibid, Art 4(1)(v)

159 Ibid, Article 42(3) and (4).

160 Ibid, Articles 42(8) and 4(1)(v).
} 
decision-making practice, in particular from the application of State aid frameworks and guidelines'. ${ }^{161}$ The underlying assumption appears to be that any potentially distortive effects of renewable energy aid exempted under the GBE Regulation are limited and outweighed by its benefits in contributing to the common objective of climate change mitigation, insofar as it is contained within the established ceilings and other conditions. ${ }^{162}$ To ensure this, any aid measure granted by Member States pursuant to the GBE Regulation is subject to transparency and reporting obligations so that the Commission can exercise ex post control of such measures. ${ }^{163}$ According to the Commission's 2016 State Aid Scoreboard, about 95\% of State aid measures implemented by Member States have been exempted under the 2014 GBE Regulation, with the general category of 'environmental protection and energy savings' taking up the largest combined expenditure ( 9.5 billion in 2015). ${ }^{164}$

Turning to the second track, the 2014-2020 Guidelines on State Aid for Environmental Protection and Energy extend the scope of the previous 2008 Guidelines on State Aid for Environmental Protection ${ }^{165}$ in the energy field (e.g., to cover aid for energy infrastructure and aid for generation adequacy measures), ${ }^{166}$ as well as adopt a more stringent approach towards renewable energy support measures. Like its predecessor, the 2014-2020 EEA Guidelines cover both investment and operating aid that does not fall within the ambit of the 2014 GBE Regulation and is thus subject to the ex ante notification requirement under Article 108(3) TFEU. However, there is no explicit exclusion of State aid contingent upon export performance or import substitution meaning that prohibited subsidies under WTO law could, in principle, be sheltered under the EEA Guidelines (unlike under the 2014 GBE Regulation). ${ }^{167}$ All environmental/energy aid measures authorised under these Guidelines are subject to annual reporting and monitoring by the Commission. ${ }^{168}$

The most salient feature of the current EEA Guidelines are the so-called 'Common Assessment Principles', which lay out an overarching 'balancing test' ${ }^{\text {'69 }}$ as the principal basis for the Commission's compatibility assessment of all notified environmental/energy aid measures. ${ }^{170}$ It comprises the following key components:

- Contribution to an objective of common interest. the planned State aid measure aims at an objective of common interest in accordance with Article 107(3)TFEU (in this context, environmental protection, the shift towards a resource-efficient and low-

\footnotetext{
${ }^{161}$ Commission Memo 2014 (n 144), at 1.

1622014 GBE Regulation (n 141), Preamble, paras 16 and 61.

163 Ibid, Chapter II.
}

164 European Commission, State Aid Scoreboard 2016',

http://ec.europa.eu/competition/state aid/scoreboard/index en.html. No specific data on renewable energy support measures is available.

165 European Commission, 'Community Guidelines on State Aid for Environmental Protection', OJ [2008] C 82/1 [2008 Guidelines]. Formally speaking, these are not formally binding on the Member States, but are so for practical purposes since they guide the Commission's assessment and decision-making on the compatibility of State aid with the internal market.

166 2014-2020 EEA Guidelines (n 51), section 1.2.

167 Ibid, section 1.1(15).

168 Ibid, section 6 .

${ }^{169}$ This test was first set out in: European Commission, 'State Action Plan - Less and better targeted State aid: a road map for State aid reform 2005-2009' COM(2005) 107final, dated 7 June 2005. It has been subsequently developed in the Commission's guidelines: see e.g., 2008 Guidelines (n 165), section 1.3.

170 This is an advance from the 2008 Guidelines (section 1.4), under which a detailed assessment under the 'balancing test' was only required in respect of certain environmental aid measures (listed in chapter 5, and including operating aid for the production of RE electricity), while for others (listed in chapter 3) there was a presumption the balancing test would lead to a positive result if the certain conditions were met (e.g., section 3.1.6 for RE investment and operating aid). 
carbon economy, and achieving a well-functioning, secure, affordable and sustainable European energy market); ${ }^{171}$

- Need for State intervention: the planned State aid measure is targeted towards a situation where aid can bring about a material improvement that the market cannot alone deliver. In particular, the Member State concerned is required to demonstrate the State aid targets a well-defined market failure hampering the achievement of the specified environmental or energy objective and which is not being addressed by other measures; ${ }^{172}$

- Appropriateness of the aid: the proposed State aid measure is an appropriate instrument to address the specified environmental or energy objective. In particular, Member States are required to demonstrate that the same positive contribution to the sought objective cannot be achieved through other less trade-distortive policy instruments or types of aid; ${ }^{173}$

- Incentive effect of the aid: the proposed State aid measure induces the beneficiary to change its behaviour to increase the level of environmental protection or to improve the functioning of a secure, affordable and sustainable energy market, and such a change in behaviour would not have occurred but for the aid; ${ }^{174}$

- Proportionality of the aid: the planned aid amount is limited to the minimum necessary to achieve the environmental or energy objective aimed for. As a general rule, aid is considered to be proportionate if it corresponds to the net extra costs necessary to achieve the relevant objective, and in the case of investment aid respects the maximum aid intensities (set out in Annex 1); ${ }^{175}$

- Avoidance of undue negative effects on competition and trade between the Member States: the negative effects of the planned State aid measure in terms of distortions on competition and intra-EU trade must be limited and outweighed by the positive effects in terms of contribution to the sought environmental or energy objective, so that the overall balance is positive. In particular, the Commission will be considering product market distortions (e.g., any negative impact of the aid on non-aided competitors of like environmentally-friendly products or technologies since this is not inherently linked to the objective of the aid) and location effects (e.g., whether the aid merely leads to a change in location of economic activity without any net improvement in the level of environmental protection); ${ }^{176}$

- Transparency of aid: Member States, the Commission, economic operators and the public should have easy access to all relevant acts and pertinent information about the aid awarded thereunder. ${ }^{177}$

In addition, the 2014-2020 EEA Guidelines provide specific compatibility criteria for certain categories of aid. With regards to RE investment aid, these mainly take the form of maximum aid intensities ${ }^{178}$ that are similar to the ones previously seen under the GBE

\footnotetext{
171 2014-2020 EEA Guidelines (n 51), section 3.2.1

172 Ibid, section 3.2.2 for further details.

173 2014-2020 EEA Guidelines (n 51), section 3.2.3.

174 Ibid, section 3.2.4.

175 Ibid, section 3.2.5.

${ }^{176} \mathrm{Ibid}$, section 3.2.6.

177 Ibid, sections 3.2.7 and 6 .

178 These reflect the need for State intervention determined, on the one hand, by the relevance of the market failure and, on the other hand, by the expected level of distortion on competition and trade: ibid, section 3.2.5.1 (77).
} 
Regulation: $45 \%, 55 \%$ and $65 \%$ of eligible $\operatorname{costs}^{179}$ respectively for large, medium-sized and small enterprises, ${ }^{180}$ with the possibility of reaching 100\% for aid provided following a competitive bidding process on the basis of clear, transparent and non-discriminatory criteria. ${ }^{181}$ Of most relevance for present purposes are the specific conditions applicable to operating aid to green electricity production, which have been considerably strengthened vis-à-vis the 2008 Guidelines. In essence, the current EEA Guidelines promote a progressive convergence of green electricity support measures through the gradual introduction of market-based aid instruments and allocation mechanisms. As a first step, for all new aid measures adopted after 1 January 2016, generators have to sell their green electricity directly in the market, and aid may only be granted as a premium in addition to the market price. ${ }^{182}$ In other words, the Guidelines seek to phase out feed-in tariff schemes commonly used by Member States, which guarantee the purchase of renewably generated electricity at regulated minimum fixed prices, and replace these by feed-in premiums that expose green electricity generators to market signals and changing electricity prices. ${ }^{183}$ In a second step, the Guidelines foresee the gradual introduction of competitive bidding as the principal means for granting aid to green electricity producers. Roughly speaking, this is a market-based mechanism for setting the premium price. During a transitional phase covering the years 2015 and 2016, aid for at least 5\% of the planned new green electricity capacity had to be provided through a competitive bidding process on the basis of clear, transparent and non-discriminatory criteria. ${ }^{184}$ From 1 January 2017, such a competitive bidding process became the general rule for allocating all operating aid granted (i.e., $100 \%$ of the planned new green electricity capacity) ${ }^{185} \mathrm{In}$ principle, this process should be technology-neutral and open to all generators producing electricity from renewable energy sources on a non-discriminatory basis. ${ }^{186}$ However, the Guidelines still allow RE technology-specific tenders to be carried out by Member States under certain conditions (e.g., if necessary to promote the long-term potential of a new and innovative technology or to achieve diversification or secure grid stability). ${ }^{187}$ Operating aid schemes compatible with these conditions are authorised for a maximum period of ten years, and if maintained after such a period, should be re-notified and reevaluated by the Commission. ${ }^{188}$

This drive towards harmonising the form and means of allocating public support to green electricity generation certainly implies a departure from the decentralised approach initially adopted under the 2009 Renewable Energy Directive, and as previously

${ }^{179}$ Defined as the extra investment costs in tangible and/or in intangible assets which are directly linked to the achievement of the environmental or energy objective, and calculated as specified therein: ibid, section 3.2.5.1 (72-76).

180 Ibid, Annex I.

${ }^{181}$ Ibid, section 3.2.5.1 (80).

$182 \mathrm{Ibid}$, section 3.3.2.1(124). In addition, beneficiaries are subject to standard balancing obligations and measures must be in place to ensure they have no incentive to generate electricity under negative prices.

183 Commission WD 2013 (n 49), at 8-9 and 12-13.

184 2014-2020 EEA Guidelines (n 51), section 3.2.5.1(126).

$185 \mathrm{Ibid}$, section 3.2.5.1(126). Only under a limited number of circumstances are Member States still allowed to grant aid without such an allocation process (e.g., to avoid strategic bidding or underbidding).

186 In this case, the Commission will presume that the aid is proportionate and does distort trade and competition to an extent contrary to the common interest: ibid, section 3.3.2.1(126).

187 Ibid, section 3.3.2.1(126).

188 Ibid, section 3.3.1(121). In addition, the Guidelines promote cross-border cooperation with the Commission giving positive consideration to MS operating aid schemes for green electricity that are open to other EEA countries and Contracting Parties of the Energy Community: section 3.3.1(122). In this regard, see also 2016 Proposed Directive (n 55), Art 5, requiring Member States to open their support schemes for green electricity to generators located in other MS under the conditions laid down therein (i.e., for at least $10 \%$ of the newly-supported capacity in each year between 2021 and 2025 and at least $15 \%$ of the newly-supported capacity in each year between 2026 and 2030). 
noted, has been enshrined in the 2016 Commission's proposal for a revised Directive within the Union's 2030 climate and energy framework. ${ }^{189}$ According to the Commission, such a move is now justified and indispensable in order to adjust current support schemes to the growing share of renewables in the European market and the decreasing costs of more established RE technologies. ${ }^{190}$ In particular, the Commission is concerned that the rigidity of administratively established FIT prices fails to take account of falling production costs, risking thereby overcompensating green electricity producers. In addition, by fully insulating beneficiaries from market price signals, FIT schemes have led to excessive production of renewably generated electricity irrespective of actual demand. ${ }^{191}$ The basic premise is, therefore, that renewables should be gradually integrated into the internal electricity market trough more flexible feed-in premiums, and government support phased out as RE technologies mature and become gridcompetitive. ${ }^{192}$ In this sense, the Commission sees genuinely competitive bidding as a self-regulating subsidy phase-out mechanism, which will reward low-cost RE technologies and eventually approach zero as technology costs reach grid parity. ${ }^{193}$ This market-based approach to green electricity support is posited as the 'only pathway' to further increase renewables in a cost-effective manner, ${ }^{194}$ by ensuring that public intervention is limited to what is necessary to correct market failures and not adding market distortions. Nevertheless, the Commission recognises that market integration may not be appropriate for small installations, which benefit from a differentiated regime under the 2014-2020 Guidelines (notably, no competitive bidding process is required ${ }^{195}$ and FITs and other equivalent forms of support are still allowed $\left.{ }^{196}\right)$.

\section{WHAT LESSONS, IF ANY, FOR THE WTO?}

As one of the most vocal proponents for 'greening' WTO subsidy disciplines through law reform rather than climate-friendly flexible interpretations as made by the Appellate Body in Canada - Renewable Energy (2013), Rubini posits that the EU's system of justifications for RE government support just examined can be a source of inspiration for the WTO in terms of rule-design and procedural mechanisms. ${ }^{197}$ At first sight, this may appear an attractive idea since there is no obvious reason why the SCM Agreement presently lacks a justification clause or other explicit basis for balancing the negative trade-distortive effects of renewable energy subsidies against their positive contribution towards the common legitimate objective of fighting climate change. In fact, this principle of balance or compromise between trade and non-trade interests is not foreign to other areas of WTO law, including the GATT where Article XX ('General

\footnotetext{
189 See section II.B above. In particular, 2016 Proposed Directive (n 55), Art 4 provides that 'Support for electricity from renewable sources shall be designed so as to integrate electricity from renewable sources in the electricity market and ensure that renewable energy producers are responding to market price signals and maximise their market revenues' and that 'Member States shall ensure that support for renewable electricity is granted in an open, transparent, competitive, non-discriminatory and cost-effective manner'.

190 Commission WD 2013 (n 49), at 4.

191 Commission Memo 2014 (n 144), at 2.

192 Commission WD 2013 (n 49), at 22.

193 Ibid, at 7.

194 Ibid, at 22.

${ }^{195}$ For this purpose, small installations are defined as those with an installed electricity capacity of less than $6 \mathrm{MW}$ of wind power (or 6 generation units), or $1 \mathrm{MW}$ of power from other renewable sources, such as solar or biomass: 2014-2020 EEA Guidelines (n 51), section 3.3.2.1(127). In the absence of a competitive bidding process, specific conditions are set out in section 3.2.2.2(131).

${ }^{196}$ For this purpose, small installations are defined as those with an installed electricity capacity below $3 \mathrm{MW}$ (or 3 generation units) for wind energy, or $500 \mathrm{~kW}$ for other sources: ibid, section 3.3.2.1(125).

197 Rubini (n 2), at 577; and Rubini (n 3), at 4.
} 
Exceptions') affords the possibility of a conditional defence for subsidies found inconsistent with GATT Article XVI. ${ }^{198}$ And yet, the proposition of drawing lessons from the EU's regulatory experience for the WTO warrants closer analysis and reflection. As we have seen, the two systems of subsidy control are fundamentally different in both substantive and procedural terms and, importantly, these differences reflect distinct objectives and political/institutional contexts. Rubini does generally recognise that the EU's regulatory approach to government support for renewable energy cannot be simply transposed as a 'single package' beyond the Union, ${ }^{199}$ but it is nonetheless necessary to fully grasp which factors limit such a direct transposition.

To begin with, EU State aid law is much more ambitious in terms of objectives, being driven by the desire to create and maintain the internal market and budgetary discipline considerations. ${ }^{200}$ As a result, the EU's regulatory system is also more farreaching in terms of the degree of control it seeks to exercise over State aid (i.e., a broad general prohibition that is effectively and centrally enforced) which is, and needs to be, counterbalanced by relatively expansive grounds for authorisation. ${ }^{201}$ Conversely, the essential purpose of the SCM Agreement is limited to providing remedies only with respect to those subsidies that have a demonstrated distortive effect on international trade flows. This in itself affords some policy space for public stimulus that is unlikely to cause such adverse effects because the subsidised products are not, or just barely, traded internationally. Precisely for this reason, as already argued, the risk of WTOincompatibility is not the same for all government measures promoting renewable energy. Significantly, this risk is much lower in the case of non-discriminatory FIT programmes in light of the limited cross-border electricity trade, which are the policy tool most widely recognised for their environmental effectiveness. The probability of WTOincompatibility is admittedly higher with regards to fiscal/financial incentives to stimulate manufacturing of RE generation equipment that is extensively traded at the global level, but consensus on their environmental effectiveness is not yet as broad. ${ }^{202}$ However, the key point is that the case for a legal shelter for green electricity subsidies is not as patently evident in the WTO context as it is under EU State aid law. Rather, it needs to be carefully construed on the basis of a proper understanding of the different legal risks to which each green electricity subsidy is exposed under WTO law. In other words, which are the measures of support that actually warrant protection under current WTO subsidy rules because they can conceivably cause trade distortions and yet are deemed desirable from a climate change mitigation perspective?

To the extent that such a trade/climate change tension really exists, may the WTO draw valuable insights from the EU's two-track justification system? In this regard, two options have been often aired in the literature for sheltering climate-friendly support measures under WTO law: (i) the revival (and renegotiation) of the expired category of non-actionable (i.e., immune from multilateral and unilateral remedies) ${ }^{203}$ subsidies under Article 8 SCM Agreement (i.e., following the logic of full exemption under the GBE Regulation); and (ii) the possible applicability of Article XX GATT or the introduction of

\footnotetext{
198 Flett (n 87), at 4-5.

${ }^{199}$ Rubini (n 2), at 577.

200 See further Bacon (n 53), at 11. Indeed, the 'balancing test' at the heart of the Commission's evaluation of notified environmental/energy State aid goes beyond weighting its contribution to achieving a legitimate objective against its trade-distortive effects, and also considers the cost-effectiveness of the aid (i.e., via the incentive effect and proportionality of aid elements). Arguably, these additional considerations are not suited to the WTO context.

201 See section III.B above.

202 See section II.A above.

${ }^{203}$ SCM Agreement, Art 8.2.
} 
a specific exception clause in the SCM Agreement (i.e., following the logic of case-bycase assessment under the EEA Guidelines).

With respect to the first option, it is doubtful that simply re-instating Article 8.2(c) SCM Agreement on non-actionable environmental adaptation subsidies would help to shield green electricity subsidies, including FIT programmes as the most commonly used and largely effective form of support. This is because the exemption devised in Article 8.2(c) SCM Agreement is quite limited in scope being subject to stringent conditions, notably: it covers only one-off non-recurring aid measures with a maximum intensity of $20 \%$ of the costs of adaption to new environmental requirements, with only extra investment costs and not operating costs being eligible. ${ }^{204}$ Nonetheless, one could argue in favour of relaxing these conditions so as to broaden the scope of the exempted environmental/energy subsidies along the lines of the GBE Regulation. ${ }^{205}$ However, there are clear hurdles in replicating this EU example at the WTO. At the outset, there is little prospect for such a reform to be politically feasible in the WTO, ${ }^{206}$ given that consensus could not be reached to renew the limited Article 8.2(c) SCM Agreement in the first place. ${ }^{207}$ Moreover, the WTO membership is comparatively more heterogeneous than the EU one in terms of both countries' individual potential for renewable energy and economic capacity to provide support. As a result, it would certainly be far more difficult to agree among over 160 W'TO members on specific criteria that pre-determine which clean energy subsidies can be presumed to be minimally trade-distortive and carve-out from SCM disciplines altogether. ${ }^{208}$ Moreover, as Bigdeli rightly notes, broadening the scope for exempting renewable energy subsidies should inevitably be accompanied by a proportionate tightening of abuse-prevention rules and monitoring procedures. Here again, the institutional capacity for subsidy surveillance in the WTO is substantially weaker, and in all likelihood there will never be an equivalent to the supranational authority and control exercised by the European Commission. ${ }^{209}$

As regards the second option, an exception clause clearly has the advantage of being more general in terms of the conditions to be established, while offering the flexibility of a case-by-case assessment of any challenged green electricity subsidy by the WTO dispute settlement organs. That being so, why not simply make GATT Article XX-defence available to violations of the SCM Agreement? Leaving aside the legal controversy over the applicability of GATT Article XX-defence to the SCM Agreement ${ }^{210}$ and assuming arguendo it does apply, ${ }^{211}$ the EU experience serves to expose

\footnotetext{
${ }^{204}$ For a more detailed examination, see Bigdeli (n 3), at 10-11 and 17-19.

205 This is suggested by Rubini (n 2), at 577, footnote 196. In a similar vein, see renewables-specific 'due restraint' clause proposed in Shadikhodjaev (n 2), at 496-497.

206 Bigdeli (n 3), at 20. In fact, renewable energy subsidies do not seem to have received dedicated attention within the WTO Negotiating Group on Rules, where negotiations take place with a view to clarifying and improving disciplines under the Anti-Dumping Agreement and the SCM Agreement in light of the Doha mandate: WTO Ministerial Conference (Fourth Session), 'Ministerial Declaration' (WT/MIN(01)/DEC/1), adopted 14 November 2001, para 28. This is sharp contrast with the case of fisheries subsidies: see most recently, WTO Negotiating Group on Rules, 'Fisheries Subsidies Compilation Matrix of Textual Proposals Received to Date' (TN/RL/W/273), dated 28 July 2017.

207 Cosbey and Mavroidis (n 2), at 41.

208 Howse (n 2), at 1.

${ }^{209}$ Bigdeli (n 3), at 20 and 36. Under the expired Art 8 SCM Agreement, non-actionable subsidies were subject to pre-notification (Art 8.3), review first by the Secretariat and then by SCM Committee with possibility of arbitration if disagreement therein (Arts 8.4 and 8.5), as well consultations and authorized remedies in case of 'serious adverse effects' to the domestic industry of another WTO member (Art 9). However, during its formal application from 1994-1999, not one single notification was made under Article 8.3 SCM, nor were the other provisions ever invoked: Bigdeli (n 3), at 8 and 11.

210 On this question, see Farah and Cima (n 15), at 1113-1116; Rubini (n 2), at 561-566; Shadikhodjaev (n 2), at 499-505.
} 
the limited suitability of this provision for justifying trade-distortive renewable energy subsidies. To some extent, the 'necessity test' of Article XX GATT ${ }^{212}$ bears some resemblance with the 'balancing test' carried out under the 2014-2020 EEA Guidelines, albeit in a simplified version. ${ }^{213}$ However, the first obvious limitation is that the environmental exception in Article XX $(\mathrm{g})$ GATT does not stipulate such a necessity test but a more flexible 'related to' requirement, ${ }^{214}$ which would not involve a balancing between the environmental effectiveness of the support measure and its trade-distortive effects. In addition, Article XX(g) GATT contains an additional condition that any measure justified therein be 'made effective in conjunction with restrictions on domestic production and consumption', which is not readily applicable to public support measures. In the alternative, renewable energy subsidies could be scrutinised under the necessity test of Article XX(b) GATT, ${ }^{215}$ but the difficulty with this test as currently interpreted is that it is focused on the trade-restrictive impact of the measure at issue, whereas the trade-distortive effects of a subsidy are not limited to impeding imports into the market of the subsidizing WTO member (as per Article 6.3(a) SCM). That could well be the most plausible adverse effects of FIT programmes but, as we have seen, other green electricity subsidies (e.g., a grant or preferential loan to manufacturers of solar panels) could conceivably cause adverse effects through increased exports of the subsidised product -e.g., in the form of 'material injury' to the import-competing interests of another WTO member (Article 5(a) SCM) or 'serious prejudice' to the export-competing interests of another WTO member in a third-country or world market (Article 6.3(c) SCM) ${ }^{216}$ Put simply, trade diversion refers to a policy measure that alters the amount and direction of trade flows down or up, and is thus a broader notion that trade restrictiveness under Article XX GATT.

But even if these limitations of Article XX GATT could be adjusted through the introduction of a specific exception clause into the SCM Agreement, this would only be made available for justifying clean energy subsidies that are directly challenged in the WTO dispute settlement system. Unlike under EU State aid law, the balancing between the positive (climate change mitigation) and negative (trade distortion) effects of renewable energy subsidies will not always be undertaken by a neutral decision-maker at the multilateral level (in casu, the WTO dispute settlement organs), since the SCM Agreement also allows for unilateral responses to certain trade-distortive subsidies by domestic authorities with an inherent tendency towards protecting local interests. ${ }^{217}$ And

\footnotetext{
${ }^{211}$ Even though this seems unlikely in light of prevailing Appellate Body's jurisprudence, which accepts the applicability of Article XX GATT for violations of non-GATT provisions only in the presence of a specific textual link: WTO Appellate Body Report, China - Measures Related to the Exportation of Various Raw Materials, WT/DS394/DS395/DS398/AB/R, adopted 22 February 2012, para. 303-306; and WTO Appellate Body Report, China - Measures Related to the Exportation of Rare Earths, Tungsten and Molybdenum, WT/DS431/DS432/DS433/AB/R, adopted 29 August 2014, paras. 5.63-5.65 and 5.74.

${ }^{212}$ WTO Appellate Body Report, Brazil - Measures Affecting Imports of Retreaded Tyres, WT/DS332/AB/R, adopted 17 December 2007 [Brazil-Retreaded Tyres (2007)], para 178.

213 Both entail an inquiry into the following: (i) whether the aid measure is aimed at an important legitimate objective of common interest; (ii) the extent to which it contributes to the achievement of the objective sought; (iii) the availability of less trade-distortive (2014-2020 EEA Guidelines) or trade-restrictive (Article XX GATT) alternatives that would make an equivalent contribution to the achievement of said objective. 214 This has been interpreted as requiring a 'close and genuine relationship' between ends and means: WTO Appellate Body Report, United States - Import Probibition of Certain Shrimp and Shrimp Products, W'T/DS58/AB/R, adopted 6 November 1998, para 141; WTO Appellate Body Report, China - Measures Related to the Exportation of Various Raw Materials, WT/DS394/395/398, adopted 22 February 2012, para 355.

215 Appellate Body Report, Brazil - Retreaded Tyres (2007) (n 212), para 151, where it suggested that climate change would fall within the objectives of Article XX(b) GATT.

216 See section III.A above.

${ }^{217}$ G. Horlick and A. Peggy, 'Rethinking Subsidy Disciplines for the Future - Synthesis of the Policy
} 
yet, as we have seen, practice thus far reveals that the main threat to governments supporting green electricity is not coming from disputes being brought to the WTO, but rather the proliferating unilateral trade remedy actions against imports of subsidised green technology products.

The aforementioned observations further corroborate the point that it is largely elusive to engage in general discussions over safeguarding policy space for government support to renewable energy under the SCM Agreement without a proper appreciation of where the 'real' constraints actually lay in the first place. These discussions ought to be informed by more consistent data on WTO members' practice in promoting green energy, as well as a clearer picture on the possible trade-distortive impact of different support measures (i.e., whether cross-border trade in the subsidised product is likely to exist or to be limited) and associated risks under WTO law (i.e., multilateral challenge or unilateral trade remedy action). In fact, the most important lesson that may be drawn from the EU's regulatory experience for the WTO is that transparency and knowledge are an indispensable prerequisite for any subsidy control system. Regrettably, as previously mentioned, the transparency procedures under the SCM Agreement have not produced the necessary breadth and depth of information on WTO members' subsidy practice. While some attempts have been made to enhance the SCM notification requirements, including the creation of a useful notification template, ${ }^{218}$ the overall compliance record remains, in the words of the SCM Committee Chair, 'discouragingly low'. ${ }^{219}$ Part of the reason may be the lack of incentives to notify, coupled with the lack of sanctions for non-notification. Here again, the EU's system mainly relies on the investigating and recovery powers of the European Commission to effectively enforce notification and transparency obligations, and is thus not easily transposable to the WTO. But as a first modest step, the existing institutional mechanisms could be used more effectively to reinforce the knowledge-enhancing side of the WTO subsidy control system. Notably, renewable energy subsidies could receive more focused attention in the context of the Trade Policy Review Mechanism and within discussions in the SCM and Trade and Environment Committees. ${ }^{220}$

\section{CONCLUSIONS}

Following the Appellate Body's report in Canada - Renewable Energy (2013), government policies to boost renewable energy and clean technologies are increasingly perceived in the academic community as the most acute testing ground for assessing the mutual supportiveness between WTO subsidy rules and climate change mitigation goals, with a growing anxiety over the need to reform the SCM Agreement and an occasional tendency to look at the EU State aid law for inspiration. While this suggestion may appear appealing at first, on closer analysis it becomes apparent that the two systems of subsidy control are fundamentally different in both substantive and procedural terms and, importantly, these differences reflect distinct objectives and political/institutional contexts. Accordingly, it is hardly conceivable, or even desirable, that the EU's regulatory approach to RE government support could be transposed to the WTO. Nonetheless,

Options' (International Centre for Trade and Sustainable Development/World Economic Forum, January 2016); and Kulovesi (114), at 354-355 on how the European Commission considered climate change policy objectives in the context of the anti-dumping investigations against cheap solar panels from China.

${ }^{218}$ WTO Committee on Subsidies and Countervailing Measures, 'Questionnaire Format for Subsidy Notifications under Article 25 of the Agreement on Subsidies and Countervailing Measures and under Article XVI GATT' (G/SCM/6/Rev.1), dated 11 November 2003.

${ }^{219}$ WTO News Item, 'Chair cites "discouragingly low” compliance with WTO subsidy notification requirements' (25 October 2016), https://www.wto.org/english/news e/news16 e/scm $280 c t 16$ e.htm.

${ }^{220}$ For a similar view, see Casier and Morenhout (n 2), at 6-7. 
this comparative analysis has been insightful in some important respects. On the one hand, the comparatively weaker constraining capacity of the WTO system in both substantive (i.e., no general prohibition on subsidies but only if proven to cause trade distortions) and procedural terms (i.e., no equivalent to Commission's supervisory and enforcement powers) logically means that the need for flexibility or policy space is not as strong or self-evident in this context as under EU State aid law. On the other hand, the less centralised control system of the WTO (i.e., permitting also unilateral trade remedy action against trade-distortive RE subsidies) also creates distinct challenges on which the EU regulatory model cannot offer much guidance.

In this sense, the Canada - Renewable Energy (2013) dispute may have placed too much emphasis on the wrong green electricity support measure (FITs with LCRs) and on the wrong WTO rules (SCM multilateral track). From the perspective of ensuring mutual supportiveness between the international trade and climate change regimes, the focus should be on whether FIT schemes without LCRs actually face genuine legal risks under current WTO subsidy disciplines. As we have seen, non-discriminatory FIT programmes are generally on a safer footing, not so much because of the flexibility created by the Appellate Body's interpretative approach to the benefit analysis in Canada - Renewable Energy (2013), but critically because the probability that such FITs can cause trade distortions is inherently limited (though not impossible) by the geographical and infrastructural constraints on cross-border electricity trade. For the opposite reason, the case of incentives (e.g., grants or preferential loans) to manufacturing of RE technology products merits more thorough analysis, particularly since these have been projected to rise substantially in the IEA's 'Bridge Scenario' whilst being increasingly exposed to unilateral countervailing and anti-dumping proceedings. However, this raises more complex questions on the relationship between climate change mitigation objectives and WTO trade remedy rules as a whole (including the Anti-Dumping Agreement).

In sum, the key point advanced here is that the case for reviewing the SCM Agreement cannot be made by simply forging parallels with the EU's system of justifications for green State aid, but needs to be carefully construed on the basis of a proper understanding of whether and how different RE support measures are impeded under the current WTO subsidy and trade remedy rules. Put differently, where exactly does the real-world trade/climate change friction actually lay? It is beyond the scope of this article to answer this question in a comprehensive manner, but it hopes to have drawn attention to the most pressing challenges in ensuring mutual compatibility between climate-friendly energy subsidies and international trade rules. Addressing them, however, requires better information on existing WTO members' practice in relation to renewable energy subsidies, as well as in-depth assessment of the environmental effectiveness and trade-distortive impact of each form of support (particularly beyond non-discriminatory FIT programmes). In fact, the most valuable lesson that the WTO can draw from the EU's regulatory experience is the imperative of improving the transparency and knowledge-enhancing side of its subsidy control system. 